\title{
34. ORGANIC GEOCHEMISTRY OF LIPIDS AND KEROGEN AND THE EFFECTS OF BASALT INTRUSIONS ON UNCONSOLIDATED OCEANIC SEDIMENTS: SITES 477, 478, AND 481, GUAYMAS BASIN, GULF OF CALIFORNIA ${ }^{1}$
}

\author{
Bernd R. T. Simoneit, ${ }^{2}$ Institute of Geophysics and Planetary Physics, University of California-Los Angeles, \\ Los Angeles, California \\ and \\ R. P. Philp, Institute of Earth Resources, Fuel Geoscience Unit, CSIRO, North Ryde, 2113 NSW, Australia
}

\begin{abstract}
Pleistocene sediments in the Guaymas Basin, Gulf of California, have been intruded by sills and their organic matter thus subjected to thermal stress. Sediment samples from DSDP/IPOD Sites 477,478 , and 481 , and samples of thermally unaltered materials from Sites 474 and 479 were analyzed to characterize the lipids and kerogens and to evaluate the effects of the intrusive thermal stresses. The lipids of the thermally unaltered samples are derived from microbial and terrestrial higher-plant detritus. The samples from the sill proximities contain the distillates, and those adjacent to the sills contain essentially no lipids. The pyrograms of the kerogens from the unaltered samples reflect their predominantly autochthonous microbial origin. When compared with the unaltered samples, the pyrograms of the altered kerogen samples reflect the thermal effects by a reduction in the complexity of the products. Kerogens adjacent to the sills produced little or no pyrolysis products. The effects of intrusions into unconsolidated, wet sediments resulted in in situ pyrolysis of the organic matter, as confirmed by these data.
\end{abstract}

\section{INTRODUCTION}

Drilling in the central Gulf of California concentrated on the Guaymas Basin and the continental slope east of that basin. The Guaymas Basin is an actively spreading oceanic basin, part of the system of spreading axes and transform faults extending from the East Pacific Rise to the San Andreas Fault System (Curray et al., 1979): It is therefore tectonically very active and consists of two rift valleys separated by a $20-\mathrm{km}$ transform fault. The basin is characterized by a high sedimentation rate, which keeps its floor and rifts covered during the formation of complex ocean crust and intrusions (Curray et al., 1979).

Site 477 is in the southern rift, and Site 481 is in the north (the locations of all Leg 64 sites are found on the area map in the introduction to shorebased geochemistry, this volume). The sediments are all late Quaternary diatomaceous ooze and turbidites intruded by various sills (Curray et al., 1979). Site 477 shows extensive hydrothermal alteration and high in situ heat flow. Site 478 is on the basin floor in the transform fault zone and consists of similar sediments with intrusives (Curray et al., 1979). Biogenic gas occurs at all sites; thermogenic hydrocarbons, ranging to $C_{7}$ and derived from the endogenous organic matter, were also detected at Sites 477 and 481 (Curray et al., 1979).

Site 479 is on the Guaymas Slope and consists primarily of diatomaceous ooze laminated below 250 meters sub-bottom (Curray et al., 1979).

\footnotetext{
${ }^{1}$ Curray, J. R., Moore, D. G., et al., Init. Repts. DSDP, 64: Washington (U.S. Govt. Printing Office). gon.
}

It was therefore of interest to examine the organic matter to evaluate two major questions: (1) the sources and characteristics of the organic matter, and (2) the effects of the thermal stress on that organic matter. The sources and characteristics of the organic matter can be determined by analyzing the lipid fractions for homologous compound distributions, for structural types of molecular markers and the nature of the unresolvable mixtures (Simoneit, 1975, 1978b, in press), and by analyzing the kerogens for their bulk compositional properties; pyrolysis/gas chromatography (GC), and pyrolysis-GC/mass spectroscopy (MS) may also be used (e.g., van de Meent et al., 1980). The effects of thermal stress on the organic matter can also be evaluated by these same lipid and kerogen analyses. Such data can then be correlated with the results of the interstitial hydrocarbon gas $\left(\mathrm{C}_{1}-\mathrm{C}_{7}\right)$ compositions.

Herewith are the data from lipid analyses of the hydrocarbon and fatty acid (as methyl esters) with ketone fractions for selected samples (Table 1). The samples are listed sequentially by sites in Table 1, and their locations are indicated to the left of each lithological column by the numerals in Figure 1 (supplemental samples are indicated by A-F).

For a variety of reasons, Curie-point pyrolysis (Cupy) of the kerogens was used to examine the effects of sills on the organic matter.

In the past few years, pyrolysis has become a powerful analytical tool, especially in studying macromolecular materials. This rapid expansion in the use of pyrolysis is the result of fast microscale flash pyrolysis techniques that appear predominantly to yield primary degradation products (Jones and Cramers, 1977). Pyrograms, obtained either by Cupy/GC or Cupy/MS, are 
Table 1. Sample descriptions and results: Carbon, lipid, and kerogen analyses, Leg 64, central Gulf of California.

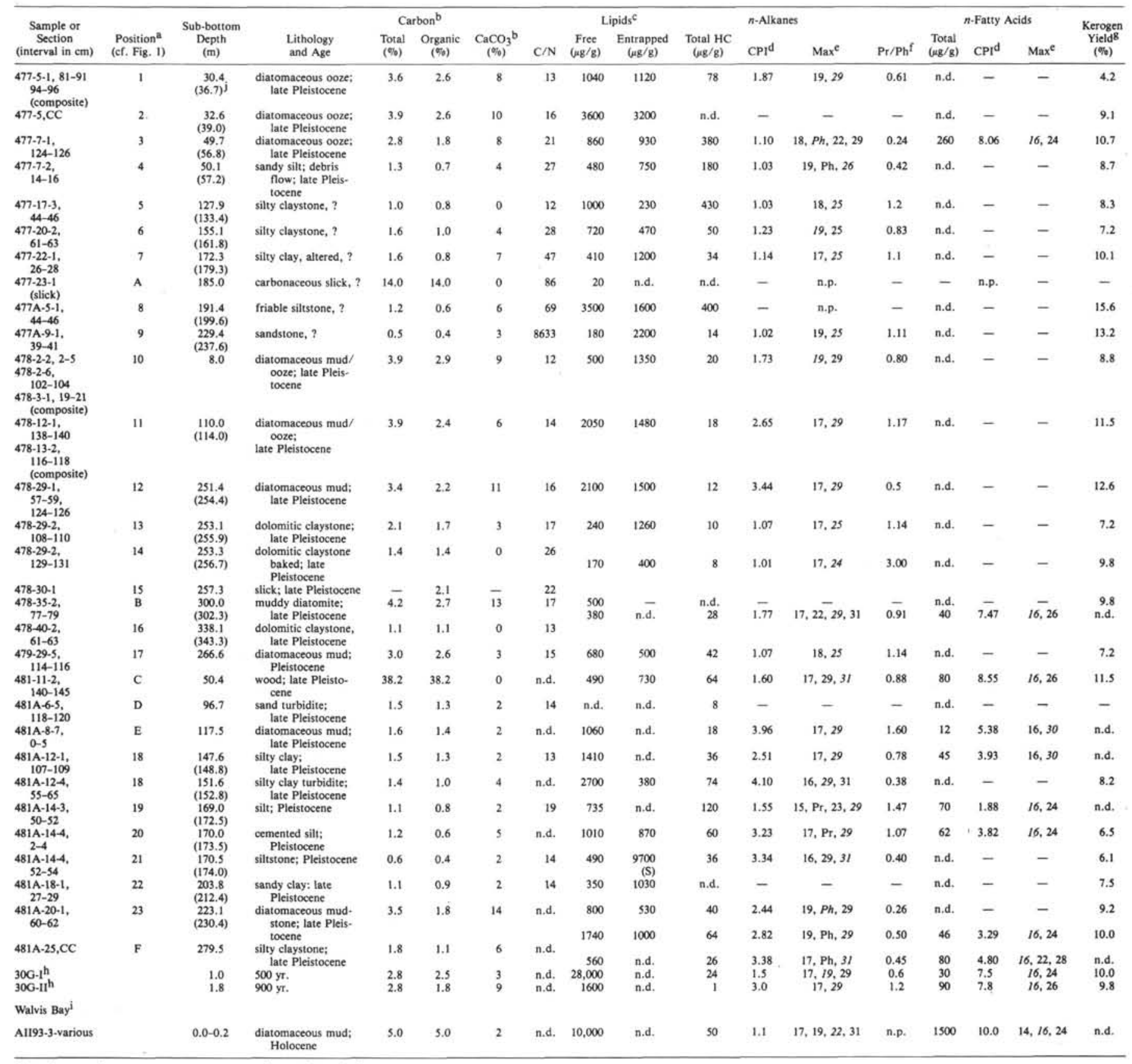

Note: $?=$ age unknown; $\mathrm{n}, \mathrm{p}$. $=$ none present; $\mathrm{n} . \mathrm{d}$. $=$ not determined.

a For analysis, various samples were combined to increase their overall amounts.
b Data supplied by Shipboard Party and University of California (Berkeley), Dept. of Chemistry, Microanalytical Laboratory.

Based on dry weight of sediment; entrapped lipids are liberated from mineral matrix after demineralization.

Carbon preference index summed from $\mathrm{C}_{12}$ to $\mathrm{C}_{35}$; odd to even for alkanes, even to odd for fatty acids.

e Dominant homolog in italics.

dyk et al. 1978)

Cupy of kerogen; yield = percentage of total dry sediment.

Data from Simoneit et al. (1979).

Depth according to DSDP convention; depth calculated upward from the core catcher is given in parenthesis (if different).

sufficiently reproducible and specific to characterize synthetic polymers, biopolymers, and geopolymers. To relate the thermal degradation products to the original macromolecule, it is necessary to identify the products and understand how they are formed. Curie-point pyrolysis-GC/MS (Simmonds et al., 1969) and pyrolysis highresolution MS, using field ionization and field desorption (Schulten et al., 1973, 1978), have yielded a great deal of information on the structure of thermal degradation products from various types of macromolecular materials. The general reaction mechanisms that form pyrolysis products are now only poorly understood, although recently substantial advances have been made (Posthumus et al., 1974; Posthumus and Nibbering, 1977a; DeJongh, 1977). Despite this shortcoming, pyrolysis techniques have been successfully employed in the 
HOLE 477

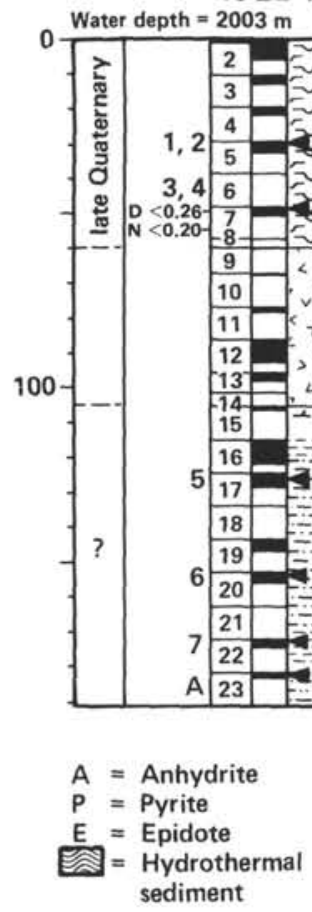

HOLE 477A

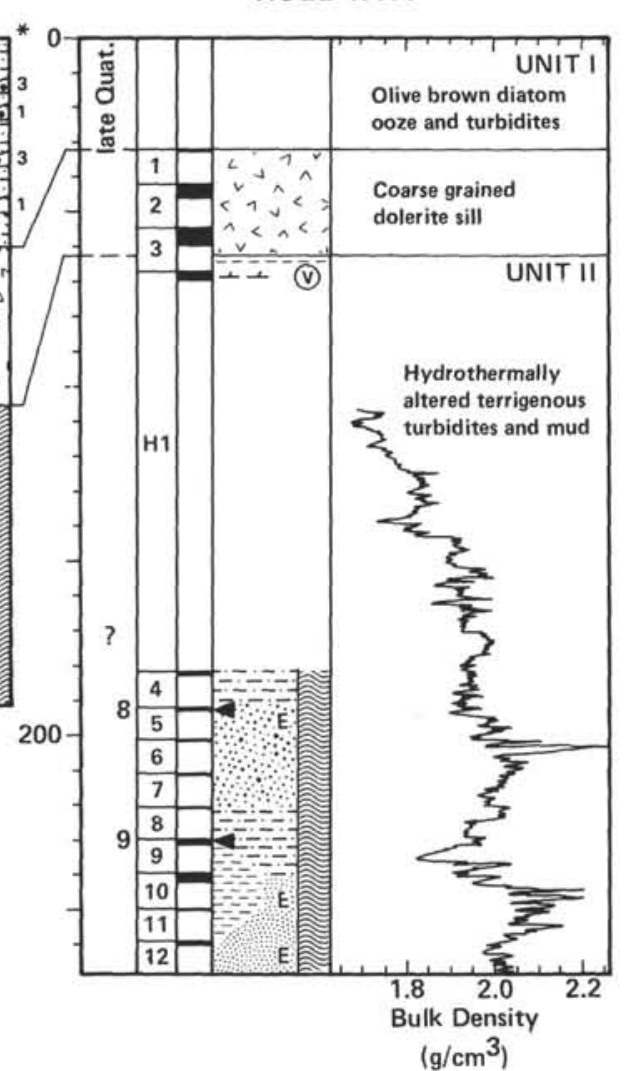

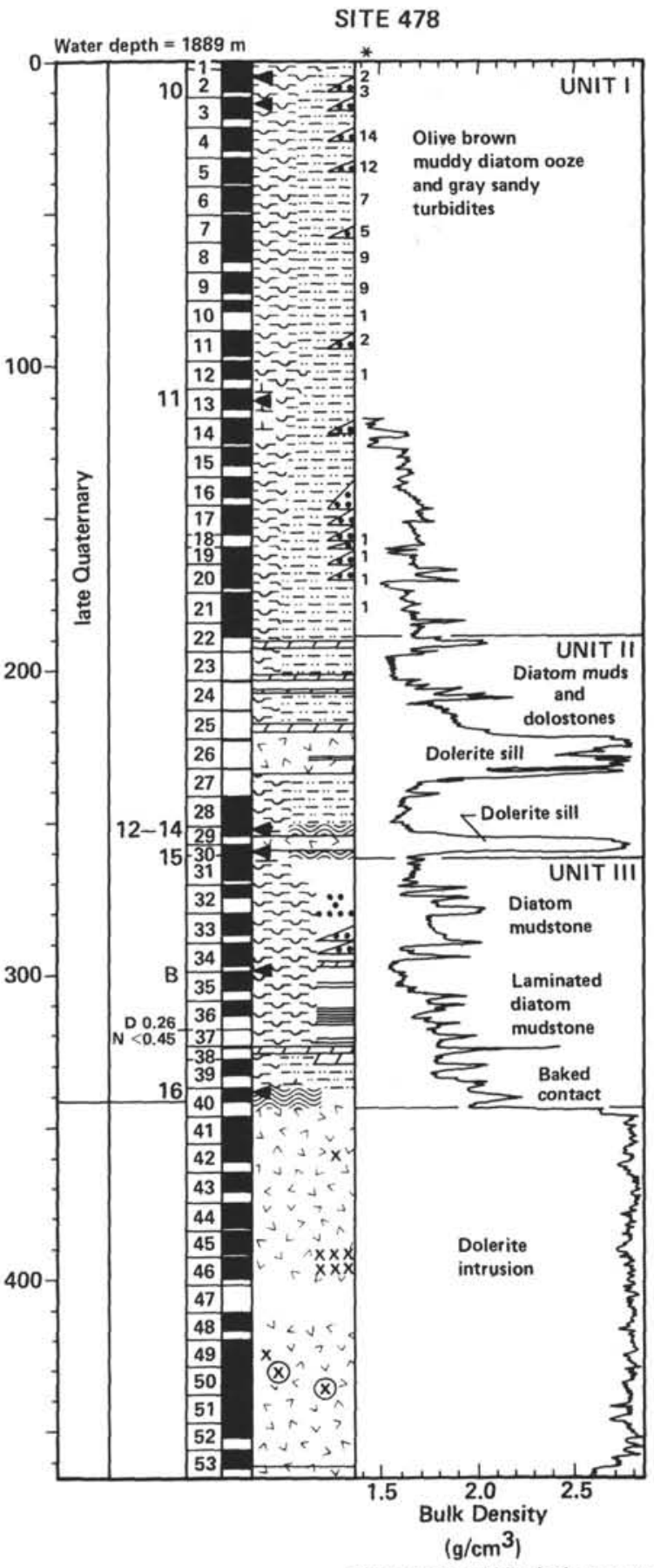

- Number of turbidite beds per core

Figure 1. Lithological columns, Holes 477, 477A, 478, 479, 481, and 481A. (Sample positions (1-23, A-F) in Table 1 are indicated.)

study of biopolymers (Meuzelaar et al., 1977), humic substances (Bracewell et al., 1976), and kerogens (Maters et al., 1977; Larter and Douglas, 1978). More recently, Cupy, with GC and GC/MS, has characterized a series of protokerogens from Recent algal mats and kerogens from DSDP core samples and ancient sediments (van de Meent et al., 1980).

In this chapter, we discuss the results obtained from kerogen pyrolysis of some of the samples listed in Table 1. We also illustrate how these results show the effects of thermal stress on the kerogens in the sill vicinities.

\section{METHODS}

Lipids. The small core samples were dried aboard ship in an oven at $45^{\circ} \mathrm{C}$ and extracted after $\mathrm{C}, \mathrm{H}, \mathrm{N}$ analysis with methylene chloride $\left(\mathrm{CH}_{2} \mathrm{Cl}_{2}\right)$. The larger samples were freeze dried and then extracted with chloroform and methanol (1:1) by ultrasonication. The extracts were concentrated on a rotary evaporator and treated with $\mathrm{BF}_{3}$ in methanol to derivatize free fatty acids. The extracts were then subjected to thin-layer chromatography (TLC) on silica gel; hexane and diethyl ether (9:1) were used for eluent. The bands (after development with iodine vapor) corresponding to hydrocarbons, esters and ketones were scraped off the TLC plates and eluted with methylene chloride. The hydrocarbon and combined ester and ketone fractions were analyzed by GC and GC/MS. 
SITE 479

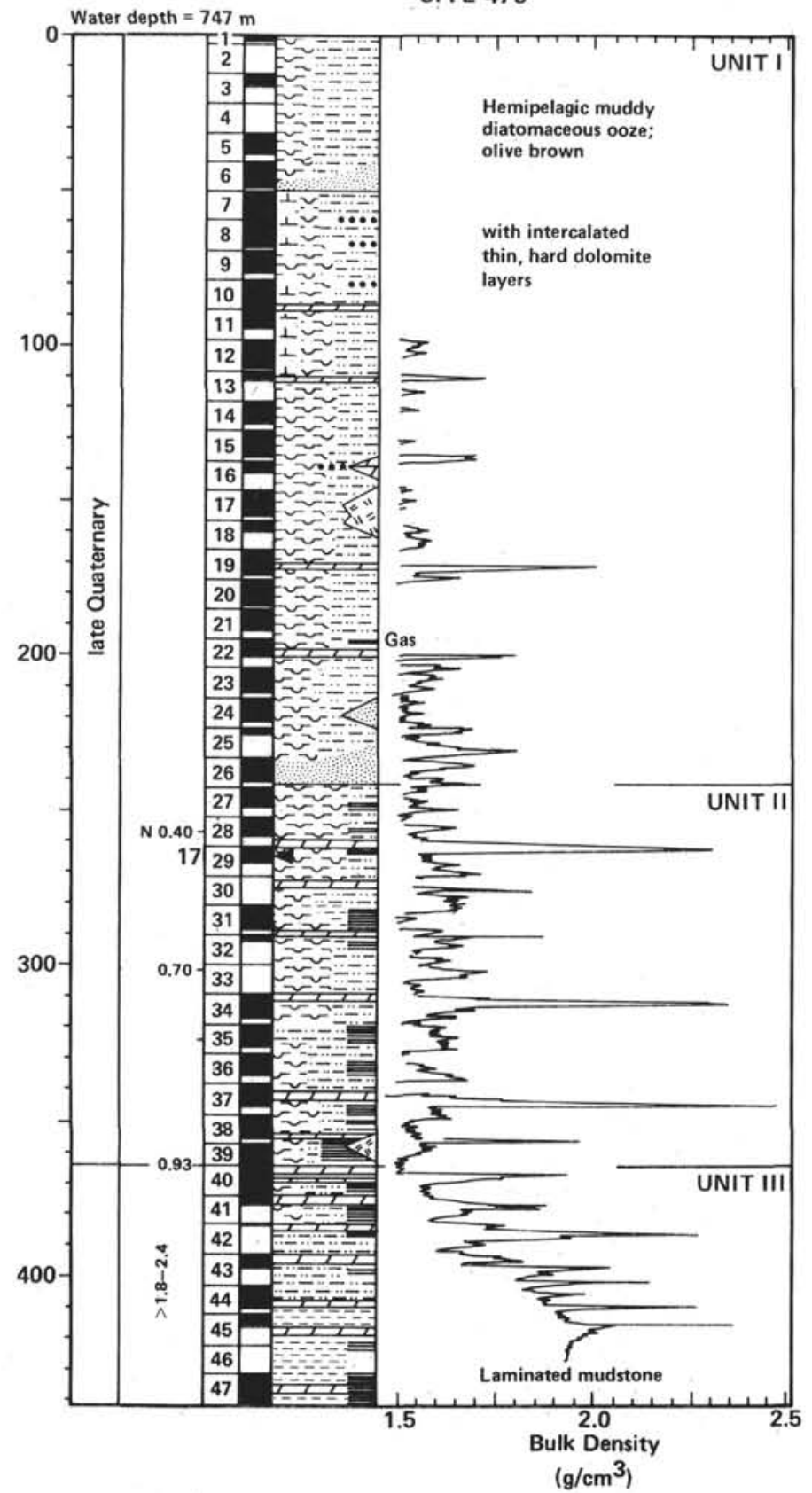

HOLE 481

Water depth $=1998 \mathrm{~m}$.

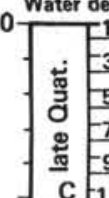

HOLE 481A

Olive brown
muddy diatom
ooze and
turbidites

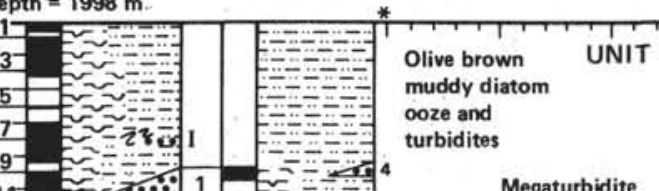


were used with the pyrolyzer to give a pyrolysis temperature of $610^{\circ} \mathrm{C}$ for $12.5 \mathrm{~s}$. A 30 -meter SP-2100 WCOT column was used in the GC/ MS system, and the temperature was programmed from 100 to $270^{\circ} \mathrm{C}$ at $4^{\circ} \mathrm{C} / \mathrm{min}$. The separator temperature was $250^{\circ} \mathrm{C}$, ion source temperature was $260^{\circ} \mathrm{C}$, filament current was $250 \mu \mathrm{A}$, electron energy was $70 \mathrm{eV}$, and scan speed was $0.95 \mathrm{~s} /$ decade.

\section{RESULTS AND DISCUSSION}

The results of the carbon and lipid analyses and kerogen yields are found in Table 1 . The total lipid contents, including the entrapped lipids liberated after demineralization, are high and consist predominantly of polar materials. The kerogen yields are also high, and they reflect a significant inorganic content.

\section{Lipids}

The lipid data will be discussed in two aspects: the nature and sources of the lipids in the surface sediments and some unaltered deeper sediments, and then the effects of the various intrusions on those lipids.

\section{Surface Samples from Sites 474,477 to 479 , and 481}

The distributions of the $n$-alkanes and fatty acids are given in Figure 2.

The lipids of the surface samples from the mouth of the Gulf of California are primarily of a marine autochthonous origin (Simoneit, this volume). This can be discerned in the example from Site 474 shown in Figure 2A and $\mathrm{H}$, where the $n$-alkanes and the $n$-fatty acids are derived mainly from microbial sources, coupled with a minor higher-plant wax component.

The shallow samples from Sites 477 and 478 reflect a lipid composition from marine and terrestrial sources in about equal proportions. The $n$-alkanes (e.g., Fig. 2B-D) range from $C_{12}$ to $C_{35}$, with maxima at $C_{19}, C_{22}$, and $\mathrm{C}_{29}$ and a strong odd-to-even carbon-number predominance $>\mathrm{C}_{24}$. The lower molecular weight homologs $\left(<C_{25}\right)$, with the associated unresolved complex mixture (hump), represent primary and degraded detritus from microbiota; the higher homologs are from vascular plant wax (Simoneit, 1975, 1980a, 1980b). The predominance of $n$-nonadecane (Fig. 2B, D) may indicate a primary bacterial residue. Phytane is the predominant isoprenoid hydrocarbon $(\mathrm{Pr} / \mathrm{Ph}<1)$, and varying amounts of sulfur and perylene are also present, indicating partially euxinic paleoenvironmental conditions of sedimentation (Didyk et al., 1978). Perylene is commonly found in Recent sediments; it probably indicates deposition under anoxic conditions, where it may derive from possible biogenic precursors of either a marine or terrigenous origin (Simoneit et al., this volume). The presence of organic or elemental sulfur (or both) is, however, less definitive in terms of paleoenvironmental conditions but does indicate a low level of oxygen (i.e., euxinic). This agrees with the lithological interpretation of a high influx of sedimentary detritus to the Guaymas Basin (Curray et al., 1979), leading to euxinic conditions where not all the organic matter can be fully degraded. The high phytane content of Sample 477-7-1, 124-126 cm (Fig. 2C) is characteristic of a more sapropelic sediment deposited under strong euxinic conditions (e.g., Simoneit, 1977a, 1980a, Simoneit et al., 1979).
Sample 479-29-5, 114-116 cm is from 267 meters sub-bottom, and its lipids are as immature as those of the surface samples. Approximately equal proportions of autochthonous marine $\left(<\mathrm{C}_{24}\right.$; Fig. $\left.2 \mathrm{E}\right)$ and allochthonous terrigenous $n$-alkanes are present. The $\mathrm{Pr} / \mathrm{Ph}$ is less than one, and both perylene and sulfur are present-again indicating partially euxinic paleoenvironmental conditions.

At Site 481 , the lipids are primarily derived from terrestrial sources. The $n$-alkanes (e.g., Fig. $2 \mathrm{~F}, \mathrm{G}$ ) range from $C_{11}$ to $C_{35}$, with maxima at $C_{17}$ and $C_{29}$ and have a strong odd-to-even carbon number predominance $>\mathrm{C}_{23}$. The minor components $<\mathrm{C}_{21}$ are derived from degraded microbial detritus, and the significant oddcarbon $n$-alkanes $\left(>\mathrm{C}_{23}\right)$ are derived from vascular plant wax (Simoneit, 1975, 1980a, 1980b). These distributions correlate with some of the surface samples from Site $30 \mathrm{G}$ (about $8 \mathrm{~km}$ to the northeast; Simoneit, et al., 1979), and the terrestrial-wax component may originate primarily from grassland and forest vegetation. The $\mathrm{Pr} / \mathrm{Ph}$ is about one (some sulfur, but no perylene, occurs) and indicates partially euxinic conditions-again, a result of the high and varying influx of sedimentary detritus by turbidite transport, which leads to a greater preservation of the organic matter.

The $n$-fatty acids exhibit bimodal distributions ranging from $\mathrm{C}_{10}$ to $\mathrm{C}_{32}$, a strong even-to-odd carbon-number predominance, and maxima at $\mathrm{C}_{16}$ and $\mathrm{C}_{24}$ or $\mathrm{C}_{26}$ or $\mathrm{C}_{30}$ (e.g., Fig. 2I-L). Most of the $n$-fatty acids from the mouth of the Gulf are marine in origin (Simoneit, this volume), and in the southern trench of the Guaymas Basin (Sites 477, 478, also 479) their origin is marine and allochthonous terrigenous. In the northern trench (Sites 481 and 30G; Simoneit et al., 1979) the distributions (e.g., Fig. 2K, L) primarily reflect a terrigenous origin from plant wax; a lesser component is derived from marine microbial sources (Simoneit, 1975). Unsaturated fatty acids were not detectable.

The aliphatic ketones consisted of only traces of $n$ alkan-2-ones $\left(\mathrm{C}_{10}-\mathrm{C}_{21}\right) ; 6,10,14$-trimethylpentadecan-2one and a minor amount of 6,10-dimethylundecan-2one for most of the shallow samples also occur. The isoprenoidal ketones reflect an origin from phytol by microbial degradation.

Dehydroabietic acid (Structure I, Appendix, this chapter), the dominant molecular marker of resinous higher plants (Simoneit, 1977b), occurs in all the shallow samples and also at Site $30 \mathrm{G}$ (Simoneit et al., 1979). Its concentration is indicated on the plots of the fatty acids (e.g., Fig. 2I-L). Dehydroabietic acid was not detected in the samples from the mouth of the Gulf (Simoneit, this volume). This confirms the influx of a terrestrial component from resinous plants to the Guaymas Basin and Slope.

The distributions of the major triterpenoids are given in Figure 3. The shallow samples at Site 477 (e.g., Fig. $3 \mathrm{~A})$ contain triterpanes ranging from $\mathrm{C}_{27}$ to $\mathrm{C}_{32}$ and consist of the hopane series (II) with primarily the $17 \alpha(\mathrm{H})$ stereochemistry and lesser amounts of $17 \beta(\mathrm{H})$ hopanes, neo-hopanes (III), hop-17(21)-ene (IV), and moretanes (V). The predominant homolog is $17 \alpha(\mathrm{H})$ - 

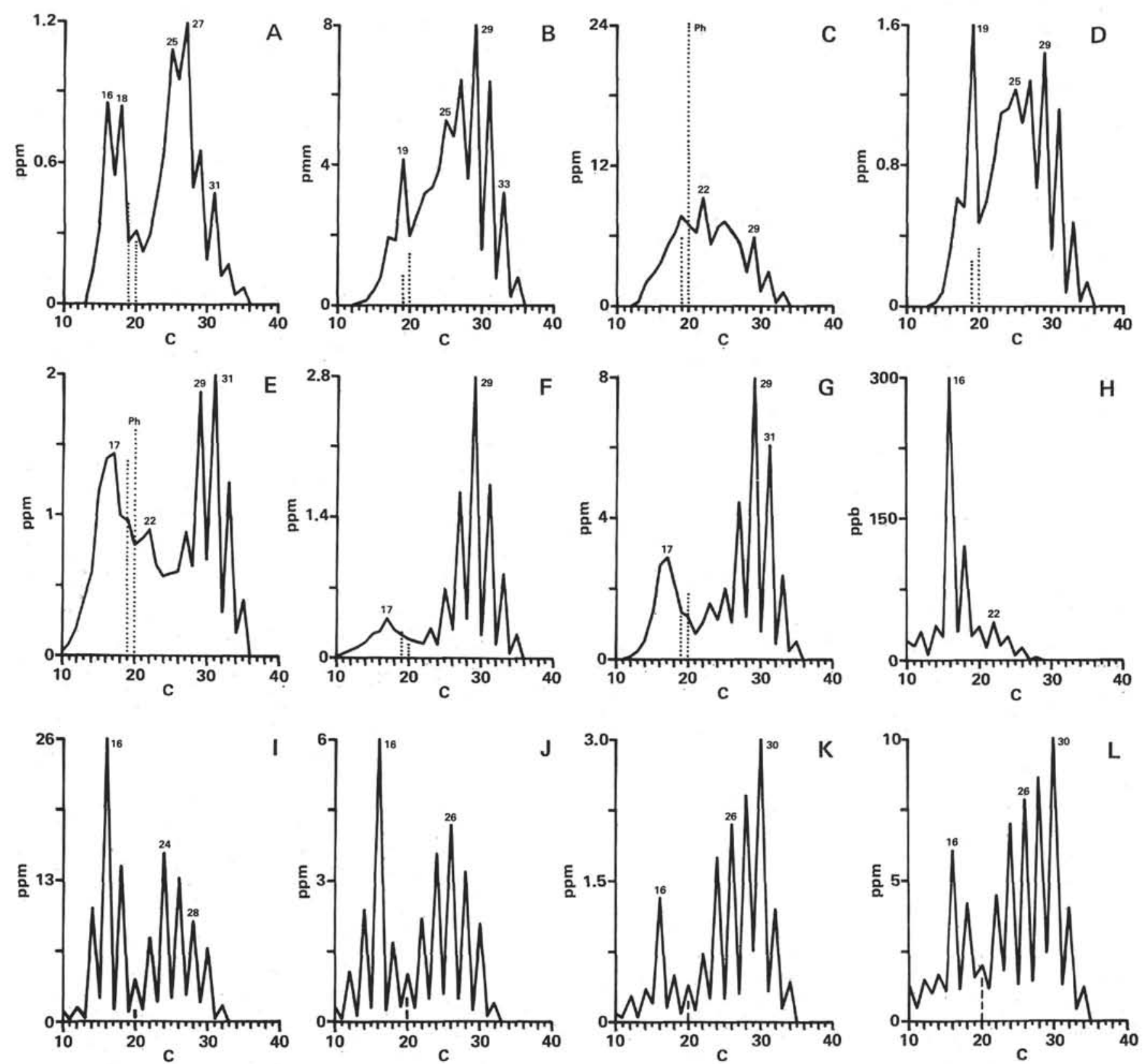

Figure 2. Distribution diagrams for the $n$-alkanes (A-G) and $n$-fatty acids (H-L) of the shallow samples, Sites $474,477-479$, and 481 . (Dotted line indicates isoprenoids; dashed line indicates dehydroabietic acid.) A, H. Section 474-5-3; B. Sample 477-5-1, 81-91 cm; C, I. Sample 477-7-1, 124-126 cm; D. Sections 478-2-2, 478-2-3, 478-2-6, 478-3-1 (composite); E, J. Sample 479-29-5, 114-116 cm; F, K. Sample 481A-6-5, 118-120 $\mathrm{cm}$; G. L. Sample 481A-8-7, 0-5 cm.

hopane; and the 22S-to-22R stereomer ratio for the $\mathrm{C}_{31}-\mathrm{C}_{34} 17 \alpha(\mathrm{H})$-hopanes is about 0.8 for the shallow samples and about 1.2 for Sample 477-7-2, 14-16 cm, which is closer to the sill. These triterpenoids are probably of an autochthonous syngenetic origin, and the predominance of the $17 \alpha(\mathrm{H})$ stereochemistry with the $22 \mathrm{~S} / \mathrm{R}$ of $\sim 1$ indicates geological maturity, probably caused by the high geothermal gradient at this site (Dastillung and Albrecht, 1976; Simoneit and Kaplan, 1980; Simoneit, this volume).

This can be compared with the triterpenoids of Sample $479-29-5,114-116 \mathrm{~cm}$ (267 m sub-bottom) and the shallow samples from Site 481 (e.g., Fig. 3H-J). In these cases the major series are the $17 \beta(\mathrm{H})$-hopanes (II) and the neo-hopanes (III); also termed iso-hopanes), with significant amounts of various triterpenes and $17 \alpha(\mathrm{H})$-hopanes. The major olefins are hop-17(21)-ene (IV) and iso-hop-13(18)-ene (VI); $17 \alpha, 18 \alpha, 21 \beta(\mathrm{H})$-28, 30-bisnorhopane (VII) occurs only in Sample 481A-6-5, $118-120 \mathrm{~cm}$, where it is the major analog (Fig. 3I). These triterpenoid distributions correlate with those at Site 30G (Simoneit et al., 1979) and they. reflect an origin primarily from autochthonous microbiota. The preponderance of the $17 \beta(\mathrm{H})$ stereochemistry of the hopanes with the presence of olefins confirms the Recent origin of these molecular markers. Iso-hop-13(18)- 

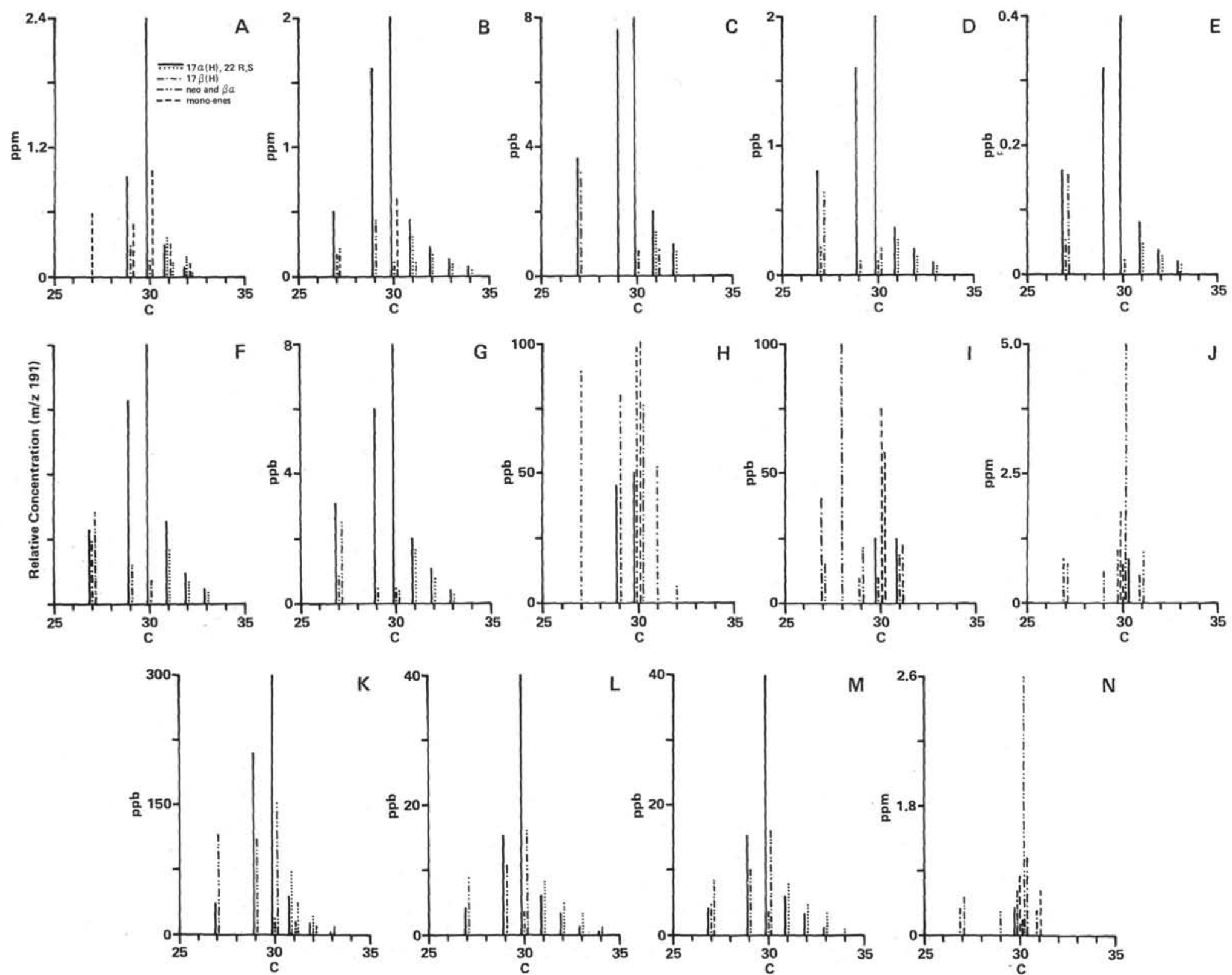

Figure 3. Distribution diagrams for triterpenoids, all sites. (Concentrations are based on the relative intensity of $\mathrm{m} / z$ 191 correlated to the GC response; $\mathrm{R}$ and $\mathrm{S}$ diastereomers of the extended homologs are also indicated; $\mathrm{C}_{28}$ compound is $17 \alpha, 18 \alpha, 21 \beta(\mathrm{H})-28,30$-bisnorhopane (VII); A. Sample 477-7-1, 124-126 cm; B. Sample 477-7-2, 14-16 cm; C. Sample 477-17-3, 44-46 cm; D. Sample 477-20-2, 61-63 cm; E. Sample 477-22-1, 26-28 cm; F. Sample 477A-5-1, 44-46 cm; G. Sample
477A-9-1, 39-41 cm; H. Sample 479-29-5, 114-116 cm; I. Sample 481A-6-5, 118-120 cm; J. Sample 481A-8-7, 0-5 cm; K. Sample 481A-12-4, 55-65 cm; L. Sample $481 \mathrm{~A}-14-3,50-52 \mathrm{~cm}$; M. Sample $481 \mathrm{~A}-14-4,2-4 \mathrm{~cm}$; N. Sample 481A-25, CC. 
ene appears to be a primary residue derived from microbiota (Howard, 1980) rather than from allochthonous sources (e.g., ferns; Ageta et al., 1968).

The fatty acid fractions of all shallow samples contain various amounts of extended $17 \beta(\mathrm{H})$-hopanoic acids (VIII), ranging from $\mathrm{C}_{31}$ to $\mathrm{C}_{33} ; 17 \beta(\mathrm{H})$-bishomohopanoic acid is the major homolog. The source of these markers is probably the bacteriohopanepolyols of autochthonous microbiota (Ourisson et al., 1979). Triterpenoidal ketones occur only as trace components.

Minor amounts of sesquiterpenoid and diterpenoid hydrocarbon residues occur in all samples. Their concentrations are highest in the shallow-and geothermally unaltered samples. They consist primarily of cadalene (IX), dehydroabietane (X), dehydroabietin (XI), retene (XII, R- $\mathrm{CH}_{3}$ ), simonellite (XIII, R- $\mathrm{CH}_{3}$ ), 1-methyl-7ethylphenanthrene (XII, $\mathrm{R}=\mathrm{H}$ ), and norsimonellite (XIII, $\mathrm{R}=\mathrm{H}$ ). These molecular markers are derived primarily from terrestrial resinous plants (Simoneit, 1977b); however, cadalene may also have an autochthonous origin from algae. Extended diterpanes (XIV) were detected in only a few thermally altered samples (from Sections 477A-5-1, 477A-9-1, and 481A-14-3), and they appear to be syngenetic with the $17 \alpha(\mathrm{H})$-hopane series.

Steroidal residues occur and were characterized mainly in the hydrocarbon fractions as steranes and sterenes (Fig. 4). The steranes in the shallow samples at Site 477 (e.g., Fig. 4A) consist primarily of the $5 \alpha-$ and $5 \beta, 8 \beta$, $14 \alpha(\mathrm{H})$-homologs $(\mathrm{XV}, \mathrm{R}=\mathrm{H})$ ranging from $\mathrm{C}_{26}$ to $\mathrm{C}_{30}$; minor amounts of the $5 \alpha$ - and $5 \beta, 8 \beta, 14 \beta(\mathrm{H})$-steranes also occur. Sterenes were not detectable. High concentrations of $5 \beta(\mathrm{H})$-steranes in these shallow samples indicate a significant maturation, probably caused by the very high thermal gradient at this site. The predominance of the $\mathrm{C}_{27}$ steranes indicates an origin from marine planktonic detritus (Huang and Meinschein, 1979); the presence of varying amounts of norcholestane (XVI) is a further indicator of such a source (e.g., Djerassi et al., 1979). Lesser amounts of 4-methylsitostane (XV, $R=$ $\mathrm{CH}_{3}, \mathrm{R}^{\prime}=\mathrm{C}_{2} \mathrm{H}_{5}$ ) and diasterenes (XVII) ranging from $\mathrm{C}_{27}$ to $\mathrm{C}_{29}$ are also present.

The steroidal compounds in the shallow or unaltered samples from Sites 478,479 , and 481 consist of steranes, primarily with the $5 \alpha(\mathrm{H})$-stereochemistry $(\mathrm{XV}, \mathrm{R}=\mathrm{H})$, diasterenes (XVII), $5 \alpha(\mathrm{H})$-ster-2-enes (XVIII), and ster4-enes (XIX) (e.g., Fig. 4F, G). Trace amounts of various steradienes also occur in some of the samples. Some of the samples from Sites 479 and 481 exhibit a predominance of the $\mathrm{C}_{29}$ sterane, which reflects the more pronounced influx of terrigenous detritus (Huang and Meinschein, 1979); this is also indicated by other lipid data.

\section{Hydrothermal Effects of Intrusives on Lipids}

The distributions of the $n$-alkanes and $n$-fatty acids of the deeper samples from Sites 477,478 , and 481 are given in Figures 5 and 6.

\section{Site $\mathbf{4 7 7}$}

Sample $477-7-1,124-126 \mathrm{~cm}$ is 1.2 to 8 meters above the sill (depending on how depths are assigned, cf. Table
1), whereas Sample $477-7-2,14-16 \mathrm{~cm}$ is only $40 \mathrm{~cm}$ closer to that sill. The differences in the hydrocarbon distributions are quite dramatic (Fig. $2 \mathrm{C}$ vs. 5A). A definite thermogenic component, with no carbon number predominance, ranging from $\mathrm{C}_{20}$ to $\mathrm{C}_{33}$ with a maximum at $\mathrm{C}_{25}$, has appeared, and the wax alkanes have disappeared. Phytane is still predominant, and the $\mathrm{C}_{17}$ and $\mathrm{C}_{19}$ hydrocarbons reflect microbial remnants. $\mathrm{A}$ broad, unresolved mixture (hump) of hydrocarbons is also evident in the GC traces of this and the following samples-further evidence of a thermogenic component. Similar hydrocarbon distributions occur below the sill in the high-heat-flow zones (e.g., Fig. 5B-E) of Holes 477 and $477 \mathrm{~A}$. As the sub-bottom depth increases, the in situ temperature rises, and these hydrocarbon distributions reflect primarily the effects of very high $\left(>350-400^{\circ} \mathrm{C}\right)$ hydrothermal activity. These hydrocarbon distributions do not compare directly with similar data for an intrusive event into semilithified, Cretaceous black shale (DSDP Site 368; Simoneit et al., 1978, 1981). In that case, the hydrocarbon distributions in close sill proximity were narrower $\left(\mathrm{C}_{12}-\mathrm{C}_{20}\right.$ only).

The molecular markers also exhibit the effects of thermal stress. The triterpenoids of Sample 477-7-2, 14$16 \mathrm{~cm}$ (Fig. 3B) are more mature or thermodynamically equilibrated than those of Sample 477-7-1, 124-126 cm (Fig. 3A). They consist primarily of the $17 \alpha(\mathrm{H})$-hopanes (II), and the extended homologs occur at a 22Sto-22R ratio of about 1.2 -very mature for such a $\mathrm{Re}$ cent sediment. Similar triterpenoid distributions occur in the samples below the sills (Fig. 3C-G) in Holes 477 and $477 \mathrm{~A}$.

The sesquiterpenoid and diterpenoid residues in the shallow samples occur only as traces or as more aromatized minor components. The extended diterpanes (XIV) occur only as trace components, and they appear to be syngenetic with the triterpanes. Steroidal residues occur mainly as steranes $(\mathrm{XV}, \mathrm{R}=\mathrm{H})$ with the $5 \alpha(\mathrm{H})$ and a significant amount of the $5 \beta(\mathrm{H})$ stereomers (Fig. $4 \mathrm{~B}-\mathrm{E})$. The predominance of the $\mathrm{C}_{27}$ steranes and the presence of norcholestane (XVI) still reflect their marine origin (Djerassi et al., 1979; Huang and Meinschein, 1979).

One major group of compounds-various olefins and di-olefins-are found only in Samples 477-7-2, 14$16 \mathrm{~cm}, 477-17-3,44-46 \mathrm{~cm}, 477 \mathrm{~A}-5-1,44-46 \mathrm{~cm}$, and $481 \mathrm{~A}-14-4,52-53 \mathrm{~cm}$. They range from $\mathrm{C}_{14}$ to $\mathrm{C}_{26}$ with an even-carbon-number predominance, and the major homologs are $\mathrm{C}_{18} \mathrm{H}_{36}$ and $\mathrm{C}_{20} \mathrm{H}_{40}$. The mass spectra of the two major olefins are shown in Figure 7. The molecular ion of $\mathrm{C}_{18} \mathrm{H}_{36}$ is at $\mathrm{m} / z 252$, and the loss of ethylene yields the even ion at $\mathrm{m} / z 224$ (Fig. 7A). Various other even-rearrangement ions are present (e.g., $\mathrm{m} / z$ 68, 168, $182,196,210)$, and the base peak is at $m / z 55$. These data indicate that this molecule is probably the terminal olefin octadec-1-ene. The analogous fragmentation is observed for eicos-1-ene (Fig. 7B). A minor series of mono-olefins, with a base peak at $m / z 70$ and no carbon number predominance, is also present. Because the samples are near a high-temperature environment, these olefins are thermogenic products derived from the protokerogen of the sediments. 

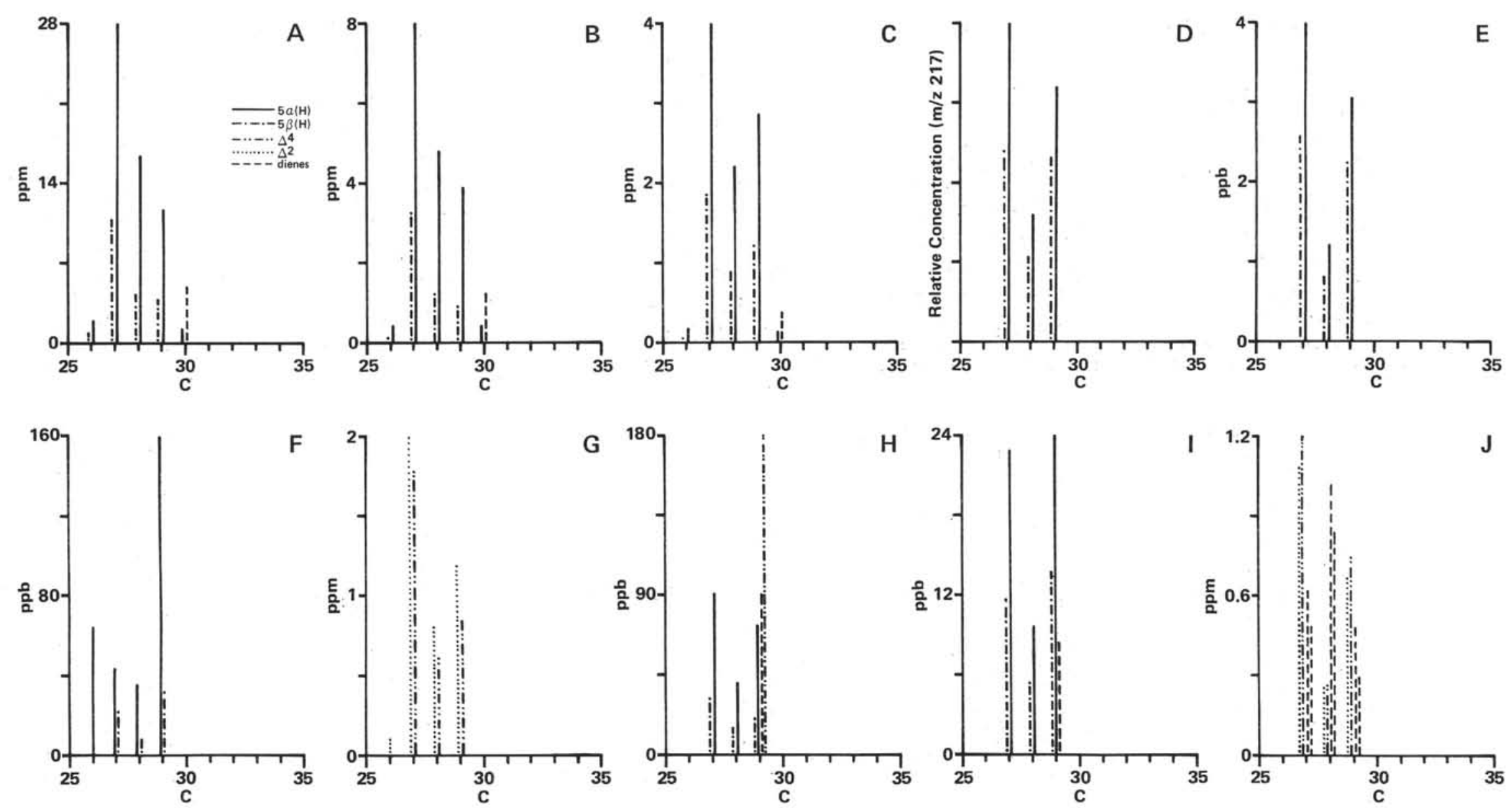

Figure 4. Distribution diagrams for steranes and sterenes. A. Sample 477-7-1, 124-126 cm; B. Sample 477-7-2, 14-16 cm; C. Sample 477-20-2, 61-63 cm; D. Sample 477A-5-1, 44-46 cm; E. Sample 477A-9-1, 39-41 cm; F. Sample 481A-6-5, 118-120 cm; G. Sample 481A-8-7, 0-5 cm; H. Sample 481A-12-4, 55-65 cm; I. Sample 481A-14-4, 2-4 cm; J. Sample 481A-25, CC. 

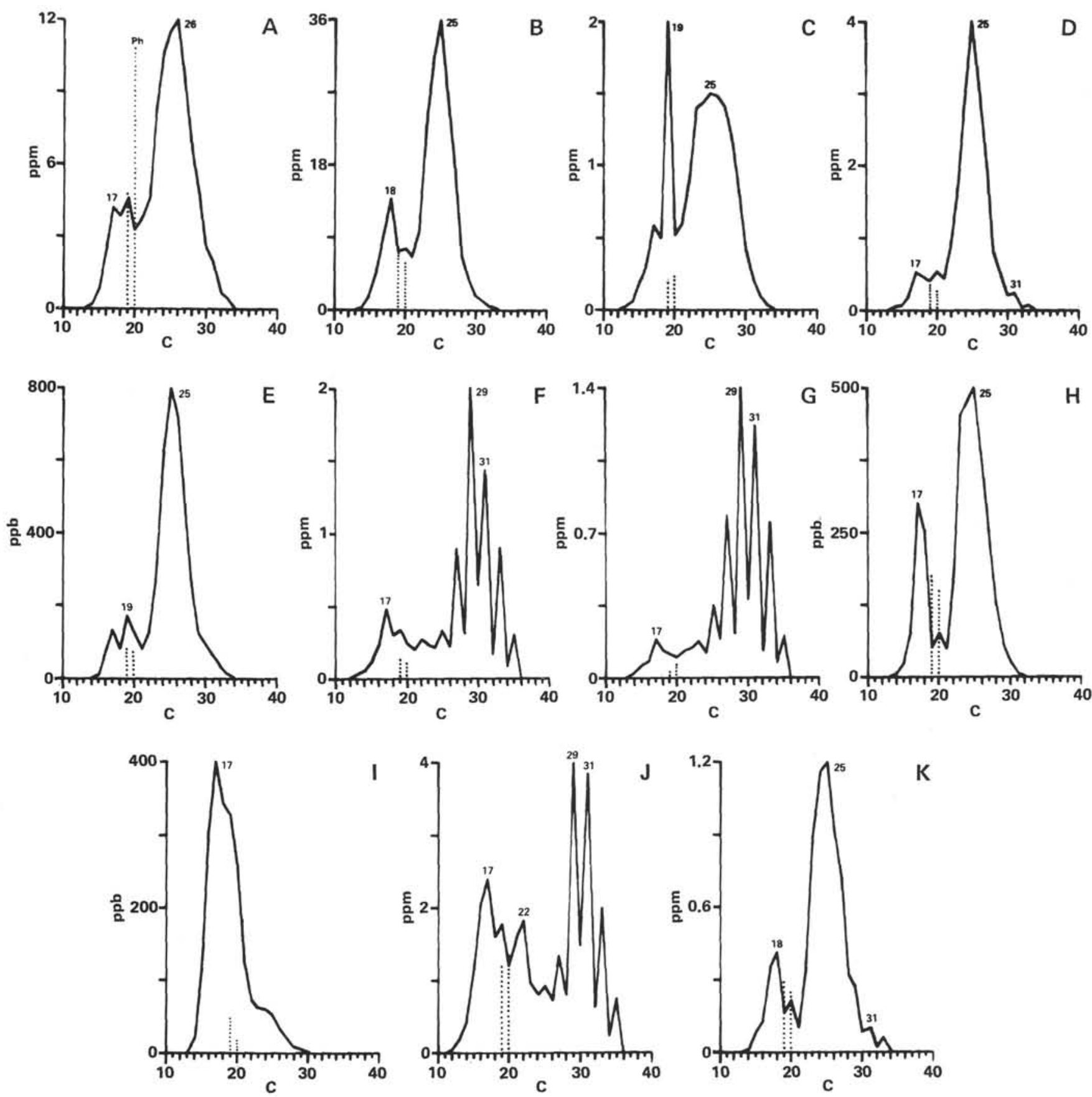

Figure 5. Distribution diagrams for $n$-alkanes, Sites 477 and 478. (Dotted line indicates isoprenoids.) A. Sample 477-7-2, 14-16 cm; B. Sample 477-17-3, 44-46 cm; C. Sample 477-20-2, 61-63 cm; D. Sample 477-22-1, 26-28 cm; E. Sample 477A-9-1, 39-41 cm; F. Sample 478-13-1/2, 131-140, 116-118 cm (composite). G. Sample 478-29-1, 57-59, 124-126 cm (composite); H. Sample 478-29-2, 108-110 cm; I. Sample 478-29-2, 129-131 cm; J. Sample 478-35-2, 77-79 cm; K. Sample 478-40-2, 61-63 cm.

These lipid fractions also contain large amounts of probably polysulfide moieties (e.g., $\mathrm{S}_{8}, \mathrm{~S}_{7}$, and $\mathrm{S}_{6}$ ). The polysulfide was probably generated by the hydrothermal activity from organic sulfur or $\mathrm{H}_{2} \mathrm{~S}$ (or both). Such polysulfide moieties also occur in euxinic sedimentary environments (e.g., the shallow sediments in the Guaymas Basin and the Southern California Borderland; Simoneit and Mazurek, 1981).

\section{Site $\mathbf{4 7 8}$}

The lipids of Samples 478-13-12, 138-140 cm, 478$13-12,116-118 \mathrm{~cm}, 478-29-1,57-59 \mathrm{~cm}$, and 478-29-1, $124-126 \mathrm{~cm}$ (below the upper sill and about $1.5-4.0 \mathrm{~m}$ above the small sill), and 478-35-2, 77-79 $\mathrm{cm}$ (below the small sill and about $40 \mathrm{~m}$ above the major sill) are immature and unaltered, reflecting the primary biogenic 

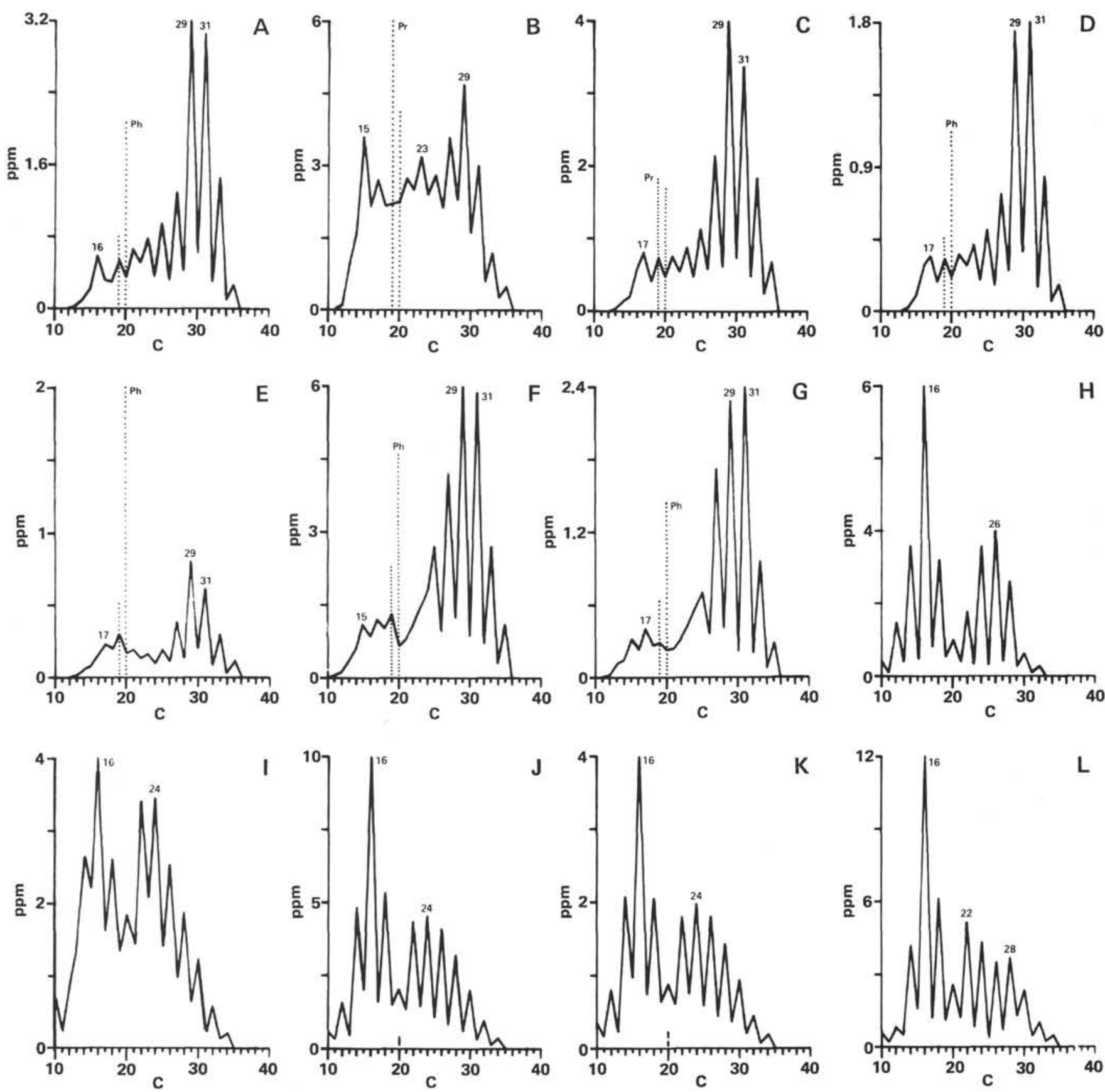

Figure 6. Distribution diagrams for the $n$-alkanes (A-G) and the $n$-fatty acids (H-L), Sites 478 and 481 . (Dotted line indicates isoprenoids; dashed line indicates dehydroabietic acid.) A. Sample 481A-12-1, 107-109 cm; B. Sample 481A-12-4, 55-65 cm; C. Sample 481A-14-3, 50-52 cm; D. Sample 481A-14-4, 2-4 cm; E. Sample 481A-18-1, 27-29 cm; F. 481A-20-1, 60-62 cm; G. Sample 481A-25, CC; H. Sample 478-35-2, 77-79 cm; I. Sample 481A-12-4, 55-65 cm; J. Sample 481A-14-3, 50-52 cm; K. Sample 481A-20-1, 60-62 cm; L. Sample 481A-25,CC.

residues (Fig. 5F, G, J; Fig. 6B). The $n$-alkanes $>\mathrm{C}_{23}$ are derived from terrestrial plant wax (as already discussed), and the homologs $<\mathrm{C}_{23}$ are of an autochthonous marine origin. The $n$-fatty acids also reflect a mixed origin from autochthonous microbiota and allochthonous plant wax (e.g., Fig. 6H).

Sample $478-29-2,108-110 \mathrm{~cm}$ is 1.8 meters below Samples 478-29-1, 57-59 cm, and 124-126 cm, and about 0.6 to 2.9 meters above a small sill ( $\sim 1.5 \mathrm{~m}$ thick). The $n$-alkanes appear typically altered $\left(>\mathrm{C}_{21}\right)$, with a remnant microbiological imprint $<\mathrm{C}_{20}$ (Fig. 5H). Sample
$478-29-2,129-131 \mathrm{~cm}$ is about $5 \mathrm{~cm}$ from the contact of the small sill and is in the hydrothermally altered zone. The $n$-alkanes confirm this (Fig. $5 \mathrm{I}$ ), because their low concentration has a very narrow distribution, similar to that of the intruded Cretaceous shales (Simoneit et al., 1978,1981 ). Sample $478-40-2,61-63 \mathrm{~cm}$ is about $80 \mathrm{~cm}$ above the lower major intrusion. The $n$-alkanes again appear typically altered (Fig. $5 \mathrm{~K}$ ), as is the case for Sample $478-29-2,108-110 \mathrm{~cm}$.

These hydrothermally altered samples do not contain any significant amounts of molecular markers (e.g., tri- 


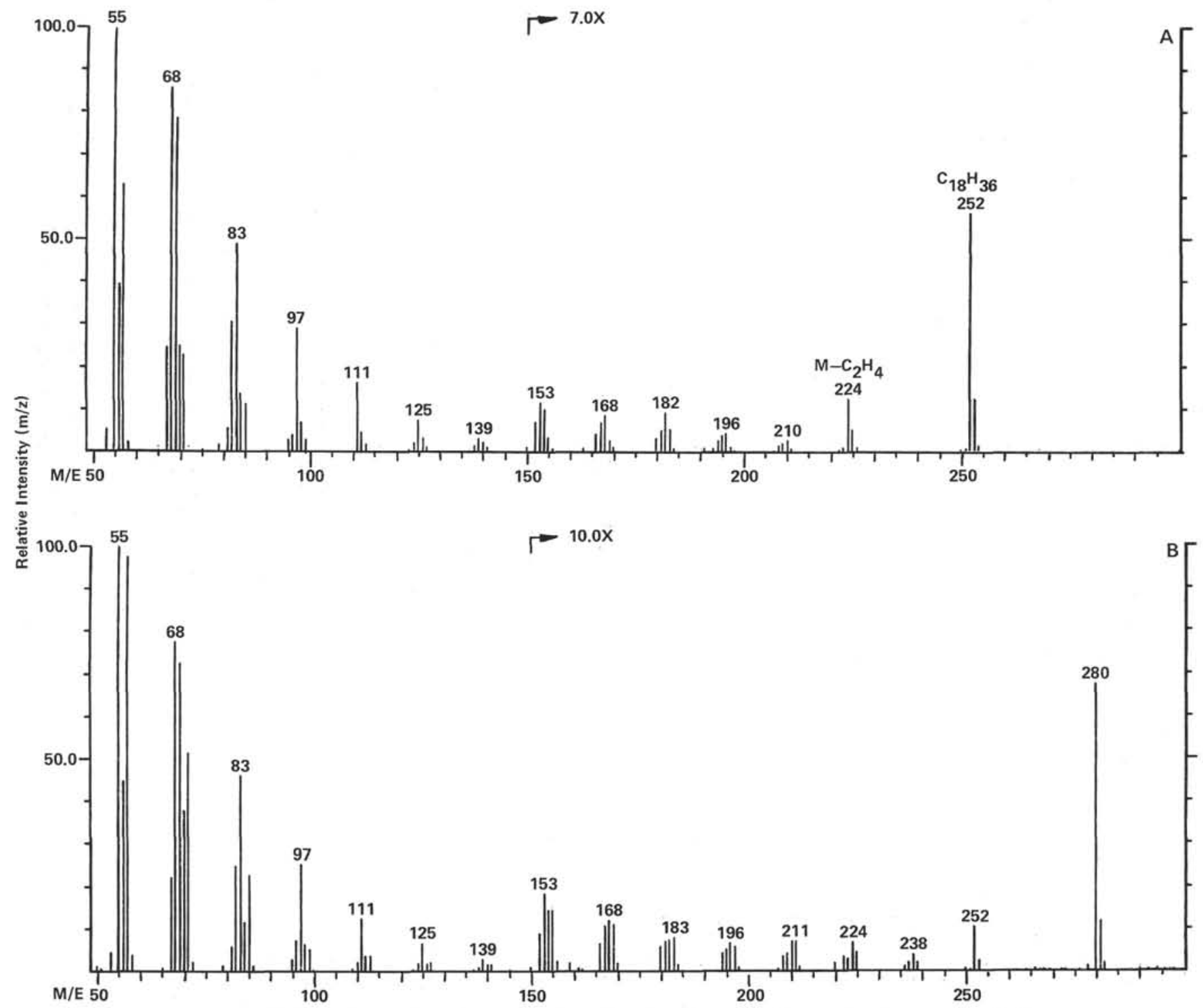

Figure 7. Mass spectra of major olefins in Sample 477-17-3, 44-46 cm. A. $n$-Octadec-1-ene, $\mathrm{C}_{18} \mathrm{H}_{36} ; \mathrm{B}$. $n$-Eicos-1-ene, $\mathrm{C}_{20} \mathrm{H}_{40}$.

terpanes) but do have high concentrations of sulfur $\left(\mathrm{S}_{8}\right.$, etc.) and some minor polycyclic aromatic hydrocarbon series. The triterpanes and other lipids may have been removed by the hydrothermal circulation.

\section{Site $\mathbf{4 8 1}$}

The lipids from Hole 481A, occurring in depth across two basalt layers, are essentially unaltered and reflect primarily their biogenic origin.

Sample 481A-12-1, 107-109 $\mathrm{cm}$ is about 25 meters above the first sill, and the $n$-alkanes (Fig. 6A) are essentially the same as those in shallow samples (e.g., Fig. $2 \mathrm{G})$. Phytane is predominant, probably the result of minor differences in paleoenvironmental conditions. Sample $481 \mathrm{~A}-12-4,55-65 \mathrm{~cm}$ is about 22 meters above the first sill, and its composition is different for the $n$-alkanes and $n$-fatty acids (Fig. 6B, I). The even-carbonnumber alkanes represent a significant proportion of the homologous series; the odd-carbon-number fatty acids are also quite high. Pristane is the predominant isoprenoid hydrocarbon. This may represent some thermogenic contribution to the natural background lipids. The distribution closely resembles others observed in the intruded Cretaceous shale (Simoneit et al., 1978, 1981) -an interpretation further strengthened by the two nextlower samples, which contain essentially no thermogenic lipids.

Sample $481 \mathrm{~A}-14-3,50-52 \mathrm{~cm}$ is about 1.5 to 5.0 meters above the sill, and the $n$-alkane- and $n$-fatty acid distributions (Fig. 6C, F) are the same biogenic fingerprints as observed in the shallow samples. The same is true for Sample 481A-14-4, 2-4 cm (e.g., Fig. 6D), about $50 \mathrm{~cm}$ (or $4 \mathrm{~m}$ ) above the sill (depths depend on convention of assignment, cf. Table 1). The $n$-alkanes are dominated by terrestrial plant wax $\left(>\mathrm{C}_{23}\right)$, with minor autochthonous microbial constituents; the $n$ fatty acids also contain both of these source components. Two explanations for the presence of these im- 
mature, unaltered lipids close to the sill are proposed. First, the true in situ distance of the samples to the sill contact may be greater because of sediment loss during drilling. Second, the section above the sill (a megaturbidite; Fig. 1), which includes these samples, may have been emplaced on a flow of basalt after cooling. This second suggestion, however, is not supported by the data from samples below the sill-they, too, are essentially unaltered.

Sample 481A-14-4, $52-54 \mathrm{~cm}$ is about $5 \mathrm{~cm}$ (or $3.5 \mathrm{~m}$; Table 1) above the sill, and it is heavily altered. The $n$-alkanes range from $\mathrm{C}_{13}$ to $\mathrm{C}_{29}$, with a maximum at $\mathrm{C}_{18}$ and essentially no carbon-number predominance. This distribution reflects the effects of thermal stress, which is further confirmed by the presence of various olefins, found only in this sample from Site 481 , and a large amount of sulfur. The major olefins are the $n$-alk-1-enes (cf. Fig. 7) ranging from $\mathrm{C}_{14}$ to $\mathrm{C}_{26}$, with a strong, evencarbon-number predominance and maximum at $\mathrm{C}_{18}$.

Sample $481 \mathrm{~A}-18-1,27-29 \mathrm{~cm}$ is about $80 \mathrm{~cm}(7.8 \mathrm{~m})$ below the sill complex. This large depth discrepancy is explained by poor core recovery and the depth assignment (Table 1). The $n$-alkanes (Fig. 6E) are dominated by terrestrial plant wax $\left(>C_{23}\right)$, a lesser microbial residue, and major isoprenoid hydrocarbons $(\mathrm{Ph} \gg \mathrm{Pr}$ ). This distribution can be correlated with a sapropelic algal sediment that received a large terrigenous influx (e.g., Simoneit, 1977a, 1978a, 1978b; Simoneit et al., 1979). Thermogenic lipids are not evident.

Samples 481A-20-1, 60-62 cm and 481A-25,CC are 23 to 34 meters and 77 meters, respectively, below the sill complex and more than 50 meters above the minor sills at depth. The distributions of the $n$-alkanes (Fig. $6 \mathrm{~F}, \mathrm{G})$ are essentially identical; terrestrial-plant-wax components predominate, and there is a minor residue of autochthonous marine lipids. These distributions are also very similar to those just above the sill complex and those in the shallow samples. Thermogenic lipids are not evident. The $n$-fatty acids (Fig. $6 \mathrm{~K}, \mathrm{~L}$ ) have bimodal distributions composed of a terrigenous influx from plant wax and an autochthonous marine component-again similar to the other samples reported.

The molecular markers of the lipids from Hole 481A show limited effects of thermal maturation, and most are immature. The diterpenoid and sesquiterpenoid residues are still present and consist primarily of dehydroabietic acid (I), cadalene (IX), dehydroabietin (XI), retene (XII, $\mathrm{R}=\mathrm{CH}_{3}$ ), simonellite (XIII, $\mathrm{R}=\mathrm{CH}_{3}$ ), 1methyl-7-ethylphenanthrene (XII, $\mathrm{R}=\mathrm{H}$ ), and norsimonellite (XIII, $\mathrm{R}=\mathrm{H}$ ).

The triterpenoids of the deepest sample (481A$25, \mathrm{CC}$ ) consist mainly of $17 \beta(\mathrm{H})$-hopanes (II), hop-17 (21)-ene (IV), other olefins, and moretanes (Fig. 3N). This distribution is very similar to that of the shallow sample from Section 481A-8-7 (Fig. 3J) and represents immature markers in the early stages of diagenesis. The triterpenoids of the other samples are more mature, with a dominance of $17 \alpha(\mathrm{H})$-hopanes (II) and $17 \beta(\mathrm{H})$ moretanes (V) and essentially no triterpenes (e.g., Fig. $3 \mathrm{~K}-\mathrm{M})$. These distributions approach the fully matured patterns at Site 477 (e.g., Fig. 3B-G) and, with the im- mature pattern below these samples, these data indicate a lesser but definite thermal effect on the molecular markers in the lipids of the sediments near the upper sill complex.

In the deepest sample, the steroidal hydrocarbon residues occur primarily as ster-2-enes (XVIII), ster-4-enes (XIX), and various steradienes (Fig. 4J). These markers are immature and are the same as those encountered in shallow samples. Samples 481A-12-4, 55-65 cm and 481A-14-4, 2-4 cm (Fig. 4H, I) contain the more mature $5 \alpha(\mathrm{H})$ and $5 \beta(\mathrm{H})$-steranes $(\mathrm{XV}, \mathrm{R}=\mathrm{H})$, with 4-methylsteranes $\left(\mathrm{XV}, \mathrm{R}=\mathrm{CH}_{3}\right)$ and only traces of sterenes. These distributions lend further support to the proposed lipid alterations caused by the thermal effects around the upper sill complex, as already discussed.

\section{Kerogen}

This section will be divided into two major portions. First, a comparison will be made between the pyrolysis products of kerogens from surface samples at each site; second, the pyrograms from the kerogens isolated from each down-hole sample will be discussed in some detail, with emphasis on the effects of the intrusions on these kerogens. The yields of kerogen are found in Table 1.

\section{Surface Samples from Sites 474, 477, 478, and 479}

The pyrograms of the kerogens from unaltered (near) surface samples from Sites 474 and 477 to 479 are shown in Figure 8. For comparison, a pyrogram of kerogen isolated from a Walvis Bay diatomaceous ooze (Namibian Shelf, SW Africa) is also shown. This kerogen represents the organic residue from diatoms in an upwelling area similar to parts of the Gulf of California. The kerogen from Sample 479-29-5, 114-116 cm (sub-bottom depth $=$ about $266 \mathrm{~m}$ ) is essentially unaltered (immature), even though it is from the Pliocene.

A comparison of the four pyrograms (Fig. 8) shows a significant similarity and provides a strong basis for the theory that the organic material being deposited at all four sites is very similar. Comparing these four pyrograms with the Walvis Bay pyrogram (Fig. 7E) also shows their very strong similarity. Thus, the bulk organic matter being deposited at the Gulf of California sites is predominantly marine, similar to the Walvis Bay diatomaceous ooze, and lacks any significant contribution from higher plants.

The major features of the pyrograms in Figure 8 can be summarized as follows:

1) They show a predominance of $n$-alkene/alkane doublets in the range $C_{10}$ to $C_{21}$ or $C_{22}$, with relatively minor amounts of higher homologs above $\mathrm{C}_{22}$. The alkene in each doublet generally dominates the corresponding alkane. The complex "humps" of unresolved components make it difficult to determine whether there is any marked even/odd predominance of these doublets. Unlike the isoprenoids, normal paraffins and olefins can originate from all kinds of lipids, and hence these products are commonly considered to be uncharacteristic (van de Meent et al., 1980). The relatively low concentration of aliphatic products in the higher-carbon-number range, however, probably reflects the rela- 

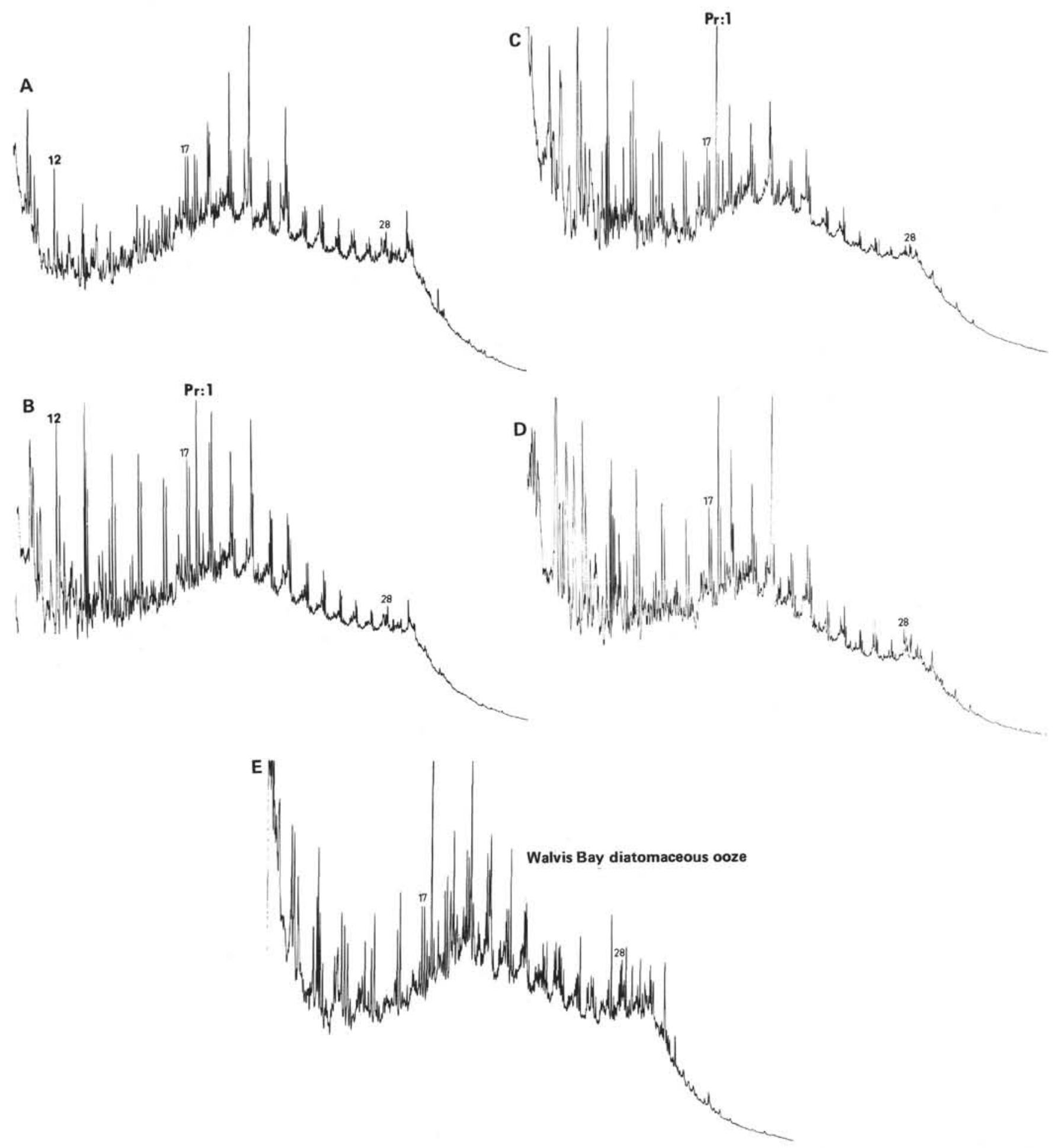

Figure 8. Examples of Curie-point pyrolysis gas chromatograms (Cupy/GC) of kerogen concentrates from shallow and unaltered samples. (Subbottom depths in parentheses; A. Sample 474-6-5, 32-34 cm (46 m); B. Sample 477-5, CC (39 m); C. Sample 479-29-5, 115-116 cm (266 m); D. Sample 478-2-2, 2-5 cm; 2-6, 102-104 cm; 3-1, 19-21 cm (composite $8 \mathrm{~m}$ ); E. Walvis Bay, SW Africa (0.5 m).

tively low abundance of long-chain structures generally encountered in the macromolecular organic matter (kerogen) of aquatic ecosystems.

2) Prist-1-ene is a prominent component of each pyrogram and generally is two or three times as concentrated as the $\mathrm{C}_{17}$ doublet. The mass spectrum of the prist-1-ene in these samples is identical to that of prist-1- ene, recently identified by Larter et al. (1979) as the major pyrolysis product of Messel shale kerogen. Pristene is one of the most abundant products in nearly all kerogens studied here. This observation is consistent with findings of other investigators (Larter [1978] and references therein). The ubiquitous occurrence of pristene in kerogen pyrolysates suggests that its source is wide- 
spread. The most commonly proposed source is chlorophyll. Chlorophyll itself, on pyrolysis, does not yield any significant quantity of prist-1-ene but instead yields phytadienes. Prist-1-ene, however, was observed in the pyrolysate of surface sediments from environments extremely rich in phytoplankton, which indicates a rapid biotransformation of chlorophyll into the pristene precursor (van de Meent et al., 1980). The one exception is the surface sample from Site 474, where pristene occurs in a much lower concentration. Each pyrogram has a second peak, present in varying amounts, which is just resolved from prist-1-ene. It is proposed that this peak corresponds to the prist-2-ene isomer. In the pyrogram of the 474 sample (Fig. 8A), prist-1-ene and prist-2-ene occur in approximately a 1:1 ratio. Prist-1-ene is a common component in pyrograms of almost all geological samples reported in the literature. The presence of prist2 -ene is not as widely reported and only appears in samples of relatively recent geological age. This introduces the possibility of using the prist-1-ene/prist-2-ene ratio as a possible early maturation indicator for samples of similar source material.

3) The pyrograms of these kerogens (Fig. 8) exhibit a complex hump of unresolved components underlying the alkene/alkane doublets already described. The humps actually have two maxima: One in the $\mathrm{C}_{18}$ to $\mathrm{C}_{20}$ region appears to consist of polar material (possibly phenolic), and another in the $\mathrm{C}_{28}-\mathrm{C}_{30}$ region may consist of a complex sterane/triterpane mixture. This complexity is clearly visible in the pyrogram of the samples from Site 478 and Walvis Bay (Fig. 8D, E). The peaks presumably represent sterane and triterpane derivatives as observed by Gallegos (1975) and Philp et al. (1978), and differences in relative concentrations probably reflect differences in source material or the environmental conditions under which it was deposited (or both).

4) Comparing these pyrograms with pyrograms obtained from immature terrestrial-type kerogens or lignite (van de Meent et al., 1980) confirms the essential absence of a higher plant contribution to these kerogens. Kerogens derived from terrestrial higher plants produced alkylphenols, and methoxyphenols in amounts significantly higher than those from other kerogens. Wax residues from higher plants occur in the pyrolysates as long-chain alkanes and alkenes with odd-andeven carbon-number predominances, respectively. Phenol humps and long-chain alkene/alkanes are found in very minor amounts in some of these kerogens.

In summary, the pyrograms of all the near-surface samples are similar to each other and to the Walvis Bay diatomaceous ooze. The pyrograms are characterized by alkene/alkane doublets (most $<\mathrm{C}_{20}$ ) and the presence of prist-1-ene and prist-2-ene. Each pyrogram also has a complex hump of unresolved components underlying the alkene/alkane doublets.

\section{Effect of Burial and Sill Intrusions on Kerogen}

\section{Site 474}

Only two near-surface samples were analyzed from Site 474. The pyrograms of kerogens isolated from Sam- ples 474-5-3, 105-107 $\mathrm{cm}$ and 474-6-5, 32-34 $\mathrm{cm}$ (Fig. $8 \mathrm{~A}$ ) are very similar to each other and to the Walvis Bay diatomaceous ooze, as has already been described.

\section{Site 477 and Hole 477A}

The pyrogram of the kerogen from Composite Sample 477-5-1, 89-91, 94-96 cm (Fig. 9A) ${ }^{3}$ is virtually identical to that for Sample 474-6-5, 32-34 cm (Fig. 8A). The pyrogram of Sample 474-6-5, 32-34 cm has already been discussed and is typical of an unaltered marine kerogen, as is the case for these samples.

The pyrogram of the kerogen from Sample 477-5,CC is shown in Figure $8 \mathrm{~B}$ and is very similar to that obtained for the kerogen from Composite Sample 477-5-1, $89-91,94-96 \mathrm{~cm}$ and the other surface samples. The major difference between the pyrograms of Sections 477-5, CC and 477-5-1 is the enhanced intensity of the alkene/ alkane doublets below $\mathrm{C}_{20}$ for the former. It is unclear whether this represents a possible variation in the composition of the organic matter of the two samples.

Sample 477-7-1, 124-126 cm is the first kerogen examined in this study that shows any effect of a dolerite intrusion. Major differences between the pyrograms of this kerogen and that in Section 477-5,CC are immediately apparent (cf. Fig. 9B). It is proposed that the differences between these pyrograms are a result mainly of the close proximity of the sill to Section 477-7-1 and not to natural diagenesis of the organic matter. The reasons for this will become apparent in the following discussion of pyrograms from the other samples at this site.

The most characteristic feature in the pyrograms of all the kerogens thought to have been affected by sill intrusions is the presence of a complex multiplet of components in the $n-\mathrm{C}_{12}$ region of their pyrograms. The overall abundance of the alkene/alkane doublets has decreased. Prist-1-ene is still present in the pyrograms, and the relative abundance of the unresolved complex hump has been reduced. It is proposed that the effect of the sill intrusions was a partial but natural pyrolysis of the organic material in the samples. This has removed much of easily pyrolyzable material responsible for the complex pyrograms of the near-surface samples. It has also somewhat altered the kerogen structure, such that subsequent Cupy/GC produces the complex, but characteristic, multiplet in the $n-\mathrm{C}_{12}$ region.

The effects of the sill intrusion are more distinct in the kerogen pyrogram for Sample 477-7-2, 14-16 cm (Fig. 9C). The multiplet of peaks in the $n-C_{12}$ region is now the most abundant feature of the pyrogram. Components in the $\mathrm{C}_{18}-\mathrm{C}_{20}$ regions of previous pyrograms are still visible but only in relatively minor quantities. None of the other features already described for the pyrograms are present. The alkene/alkane doublets are absent; prist-1-ene and prist-2-ene are absent, and the pyrogram is devoid of any complex hump of unresolved components. The source of these traces of volatilizable compounds is unknown.

Sample 477-17-3, 44-46 cm was collected approximately 25 meters below the bottom of the sill. The kero-

\footnotetext{
${ }^{3}$ For analysis, various samples were combined to increase their overall amounts.
} 


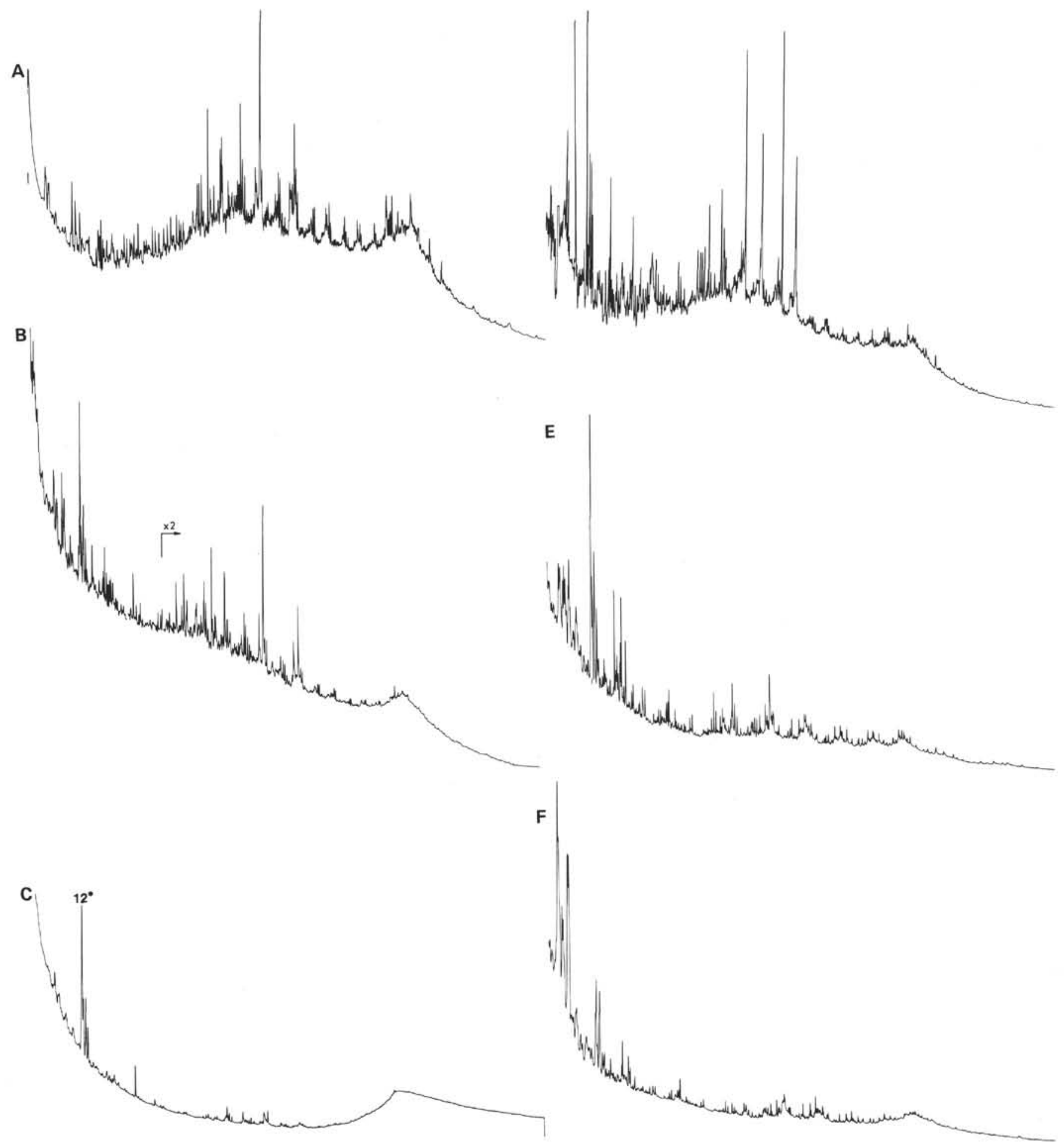

Figure 9. Examples of Cupy/GC traces of kerogen concentrates from Site 477 versus depth. (Sub-bottom depths in parentheses.) A. Sample 477-5-1, 87-91, 94-96 cm (30 m) (composite); B. Sample 477-7-1, 124-126 cm (50 m); C. Sample 477-7-2, 14-16 cm (50+ m; *designates the C 12 retention region); D. Sample 477-22-1, 26- $28 \mathrm{~cm}$ (172 m); E. Sample 477A-5-1, 44-46 cm (191 m); F. Sample 477A-9-1, 39-41 cm (240 m).

gen pyrogram is virtually identical to that obtained from Sample 477-7-2, 14-16 cm (Fig. 9C) which was 0.8 to 7.6 meters from the top of the sill. If a comparison is made of pyrograms of kerogens from similar distances above and below the sill, it appears that kerogens below the sill have been affected slightly more by the heat than those above the sill. Two explanations are available: Heat transfer through the underlying sediments from the sill is more efficient, or the underlying sediments are affected both by the heat from the sill and a greater heat flow from depth. A firm conclusion on this matter cannot be drawn from the available evidence. 
Sample 477-20-2, 61-63 cm was collected 50 meters below the sill. The pyrogram shows that the kerogen has been altered, most probably by the effect of the sill plus a small contribution of heat flow from depth. The only feature of the pyrogram is the multiplet of components in the $n-C_{12}$ region. No additional pyrolysis products could be detected.

The pyrogram of kerogen (Fig. 9D) isolated from Sample 477-22-1, 26-26 cm, collected 75 meters below the sill, shows signs of being less altered than the kerogens of Samples 477-17-3, 44-46 cm and 477-20-2, 61$63 \mathrm{~cm}$. The multiplet in the $n-\mathrm{C}_{12}$ region occurs in this pyrogram, but prist-1-ene, alkene/alkane doublets, and indications of a sterane/triterpane mixture in the $\mathrm{C}_{30}$ region are also present. It is proposed that, at this depth, slight alteration of the kerogen has occurred by the natural heat-flow phenomena, and the kerogen has not been affected by the sill intrusion.

The pyrogram also has four relatively intense peaks in the $\mathrm{C}_{19}-\mathrm{C}_{22}$ region. Two of these have been identified by $\mathrm{GC} / \mathrm{MS}$ as the $\mathrm{C}_{16^{-}}$and $\mathrm{C}_{18^{-}}$-saturated fatty acid methyl esters. Their presence in the pyrogram is puzzling. The possibility that they are contaminants from the pyrolysis wire cannot be eliminated. All the wires were cleaned and handled in the same fashion, but these compounds occur only in certain pyrograms. By analogy, it is unlikely that they are contaminants in the kerogen, simply because of the isolation procedure. If these compounds are not artifacts, it is proposed that they were trapped in the kerogen and released by pyrolysis at $600^{\circ} \mathrm{C}$.

The major peaks of the pyrogram of Sample 477A$5-1,44-46 \mathrm{~cm}$ (Fig. 9E) are to be found in the multiplets in the $n-\mathrm{C}_{12}$ region. Relatively small amounts of alkene/ alkane doublets and broad peaks, probably phenolictype compounds, also occur in the region above $C_{20}$. These phenolic-type compounds may be present in previous pyrograms but are not easily observable because of the much higher abundance of the alkene/alkane doublets.

Sample $477 \mathrm{~A}-9-1,39-41 \mathrm{~cm}$ is the deepest material from this site. The pyrogram obtained for this kerogen (Fig. 9F) does not differ significantly from that already described for Sample 477A-5-1, 44-46 cm (Fig. 9E). Again, it is proposed that it is the effect on the organic matter of the high heat flow from depth, and not from the sill, which has caused the alteration of the kerogen.

\section{Site $\mathbf{4 7 8}$}

Cores recovered at this site range from 0 to 464 meters sub-bottom. Dolerite sills intruded the section at 230 and 255 meters. Samples for this study were obtained from the surface, from between the sills, from below the lower and smaller sill at about 260 meters, and from another location at about 340 meters (just above the major dolerite).

Composite Sample 478-2-2 (2-5 cm), 2-6 (102-104 $\mathrm{cm}), 3-1(19-21 \mathrm{~cm})$ has a kerogen pyrogram that is virtually identical to the other surface samples (Fig. 8). It is dominated by alkene/alkane doublets in the range $\mathrm{C}_{10}$ to $\mathrm{C}_{30}$, which are predominant in the region below $\mathrm{C}_{20}$.
Prist-1-ene and prist-2-ene are present in a ratio of approximately $3: 1$. Two prominent peaks in the $\mathrm{C}_{18}$ and $\mathrm{C}_{20}$ region of the pyrograms have been tentatively identified as the $\mathrm{C}_{16^{-}}$and $\mathrm{C}_{18}$-fatty acid methyl esters previously described in the GC/MS analysis of Sample 477$22-1,26-28 \mathrm{~cm}$. A complex mixture of steranes and triterpanes also occurs in the $\mathrm{C}_{30}$ region.

Composite Sample 478-12-2 (81-83 cm), 13-1 (138$140 \mathrm{~cm}), 13-2(116-118 \mathrm{~cm})$ occurs at approximately 110 meters sub-bottom, and the pyrogram of the resulting kerogen is not dominated by the characteristic signs of thermal alteration previously observed in the pyrograms already discussed. Although the multiplet in the $n-\mathrm{C}_{12}$ region-common to the other pyrograms of thermally altered kerogens-occurs in this pyrogram, the major components are still the alkene/alkane doublets. Prist1-ene and prist-2-ene occur in a 1:1 ratio. There appears to be a slight even/odd predominance of the alkene/alkane doublets, but because the doublets are superimposed on the complex hump, it is unrealistic to attach any great significance to this observation.

Composite Sample 478-29-1 (57-59 cm), 29-1 (124$126 \mathrm{~cm}), 29-2(34-36 \mathrm{~cm})$ occurs 5 to 7 meters above the minor sill (254 m sub-bottom), and the kerogen pyrogram (Fig. 10A) shows a remarkable absence of any signs of thermal alteration. The pyrogram is dominated by alkene/alkane doublets with carbon numbers primarily $<\mathrm{C}_{20}$ and extending to $\mathrm{C}_{30}$; prist-1-ene and prist2-ene are present in a 1:1 ratio, steranes and triterpanes occur in the $\mathrm{C}_{30}$ region, and the underlying complex hump of unresolved components is also present. It must be speculated that the heat flow resulting from this narrow intrusion was not great enough to significantly alter this sample.

Sample 478-29-2, 108-110 cm, approximately 0.4 to 3 meters from the sill, shows some effects of thermal alteration from the intrusion. In the pyrogram (Fig. 10B) the unresolved complex humps are absent; prist-1-ene dominates prist-2-ene, and the relative intensity of the alkene/alkane doublets is reduced. In addition, a fairly well-resolved complex mixture of components is now present in the $\mathrm{C}_{17}-\mathrm{C}_{21}$ region.

Sample $478-29-2,129-131 \mathrm{~cm}$ is 0.2 to 2.8 meters from the sill contact, and the kerogen pyrogram confirms more extensive thermal alteration than in Sample 478-29-2, 108-110 cm. The predominance of the multiplet in the $n-\mathrm{C}_{12}$ region of the pyrogram is a good indication of the sample's extensive alteration resulting from the intrusion. The relative intensity of the alkene/ alkane doublets has been further reduced. The complex mixture in the $\mathrm{C}_{17}-\mathrm{C}_{22}$ region is still evident and similar to that observed in the pyrogram of 478-29-2, 108-110 $\mathrm{cm}$. Although not confirmed by GC/MS, the major peaks in this region are probably the $\mathrm{C}_{16}$ - and $\mathrm{C}_{18}$-fatty acid methyl esters as described for Sample 477-22-1, 26$28 \mathrm{~cm}$ (Fig. 9D).

The carbonaceous slick in Section 478-30-1 also reflects the thermal stress of that sill, as can be seen in Figure 10C. The amount of pyrolyzable material is reduced, but the characteristics of a thermally altered sample are still visible in the pyrogram. The alkene/alkane 


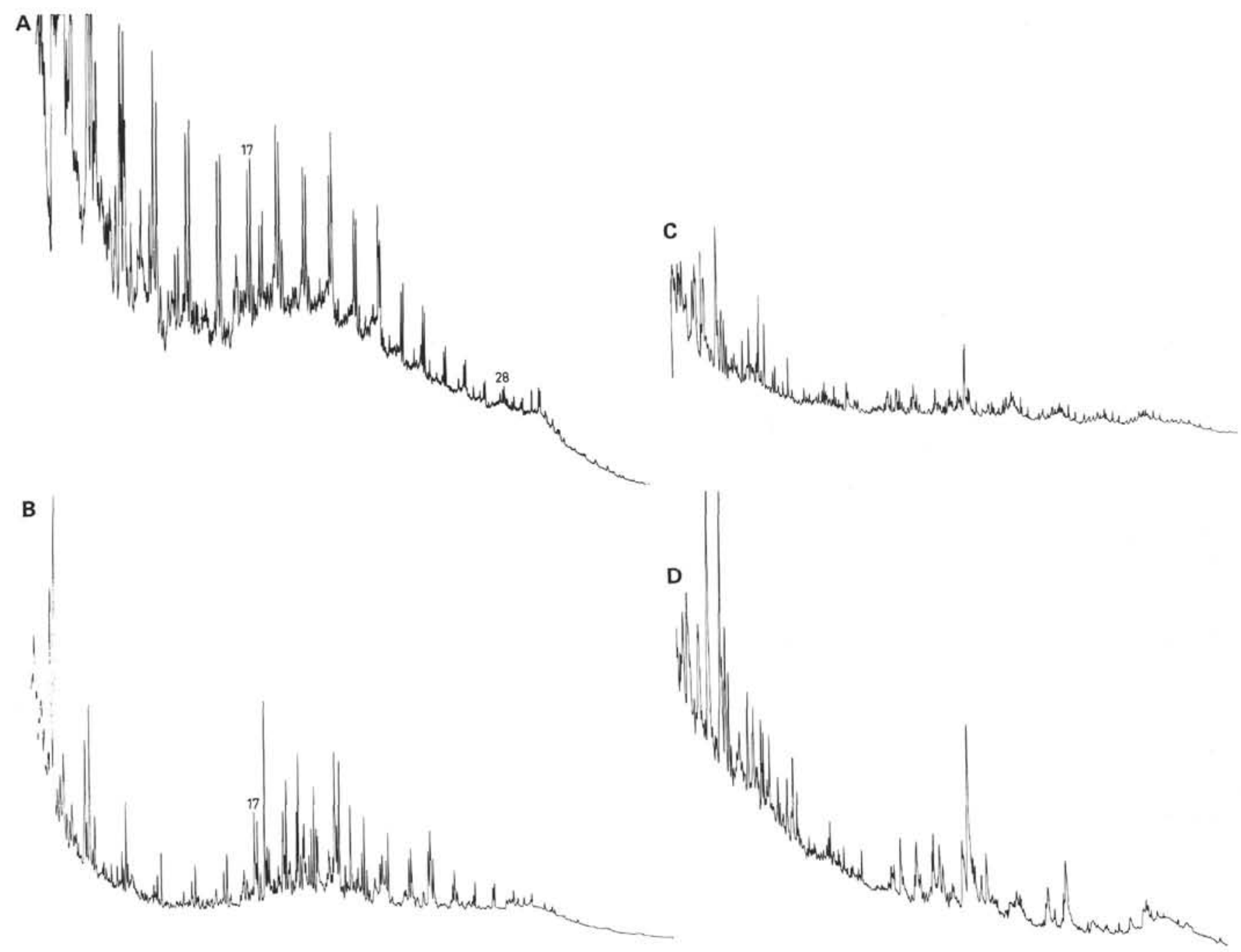

Figure 10. Examples of Cupy/GC traces of kerogen concentrates, Site 478. (Sub-bottom depths in parentheses.) A. Sample 478-29-1 (57-59 cm), 29-1 (124-126), 29-2 (34-36 cm) (composite $250 \mathrm{~m})$; B. Sample 479-29-2, 108-110 cm (253 m); C. Section 478-30-1 (257 m; slick); D. Sample $478-40-2,61-63 \mathrm{~cm}(378 \mathrm{~m})$.

doublets are absent, and the appearance of a series of well-defined humps of polar material can now be observed in the $\mathrm{C}_{17}-\mathrm{C}_{22}$ region of the pyrogram.

Sample 478-40-2, 61-63 cm occurs about 340 meters sub-bottom, which eliminates any possibility of alteration of the organic material by the lower sill at 255 meters. The major cause of alteration, however, is probably the major dolerite immediately below the sample. The pyrogram (Fig. 10D) is very similar to that for the slick already described (Fig. 10C). The multiplet in the $n-\mathrm{C}_{12}$ region is present, and the alkene/alkane doublets and prist-1-ene are absent. The phenolic-type humps occur in the $\mathrm{C}_{17}-\mathrm{C}_{22}$ region.

\section{Site 481}

The shallowest sample from this hole occurs at a depth of 147.5 meters; therefore, no direct comparison has been made with the surface samples from the other sites. Changes in the pyrograms of these samples with increasing sample depth, however, clearly show that alteration has been caused by the intrusions and not by the natural geothermal gradient.

Sample 481A-12-1, 107-109 cm occurs about 25 meters above the sill complex (170.5-203 m) and the kerogen pyrogram is already showing certain signs of thermal alteration (Fig. 11A). The multiplet has partially developed in the $n-\mathrm{C}_{12}$ region, and the complex humps in pyrograms of surface samples from other sites are essentially absent. The pyrogram is dominated by alkene/alkane doublets ranging from $\mathrm{C}_{10}$ to $\mathrm{C}_{30}$ and maximizing between $\mathrm{C}_{18}$ and $\mathrm{C}_{20}$. The presence both of prist-1-ene and prist-2-ene in a ratio of about 1:1 suggests that the sample has undergone only limited alteration. Previous pyrograms obtained in this study indicate that prist-2ene tends to be absent if the sample has been substantially altered. Steranes and triterpanes are present in the $\mathrm{C}_{30}$ region of the pyrogram.

Sample 481A-14-3, 50-52 cm is the first of three samples from the immediate vicinity of the sill complex. The pyrogram (Fig. 11B) has many of the characteristics observed in the pyrograms of previous samples that were 


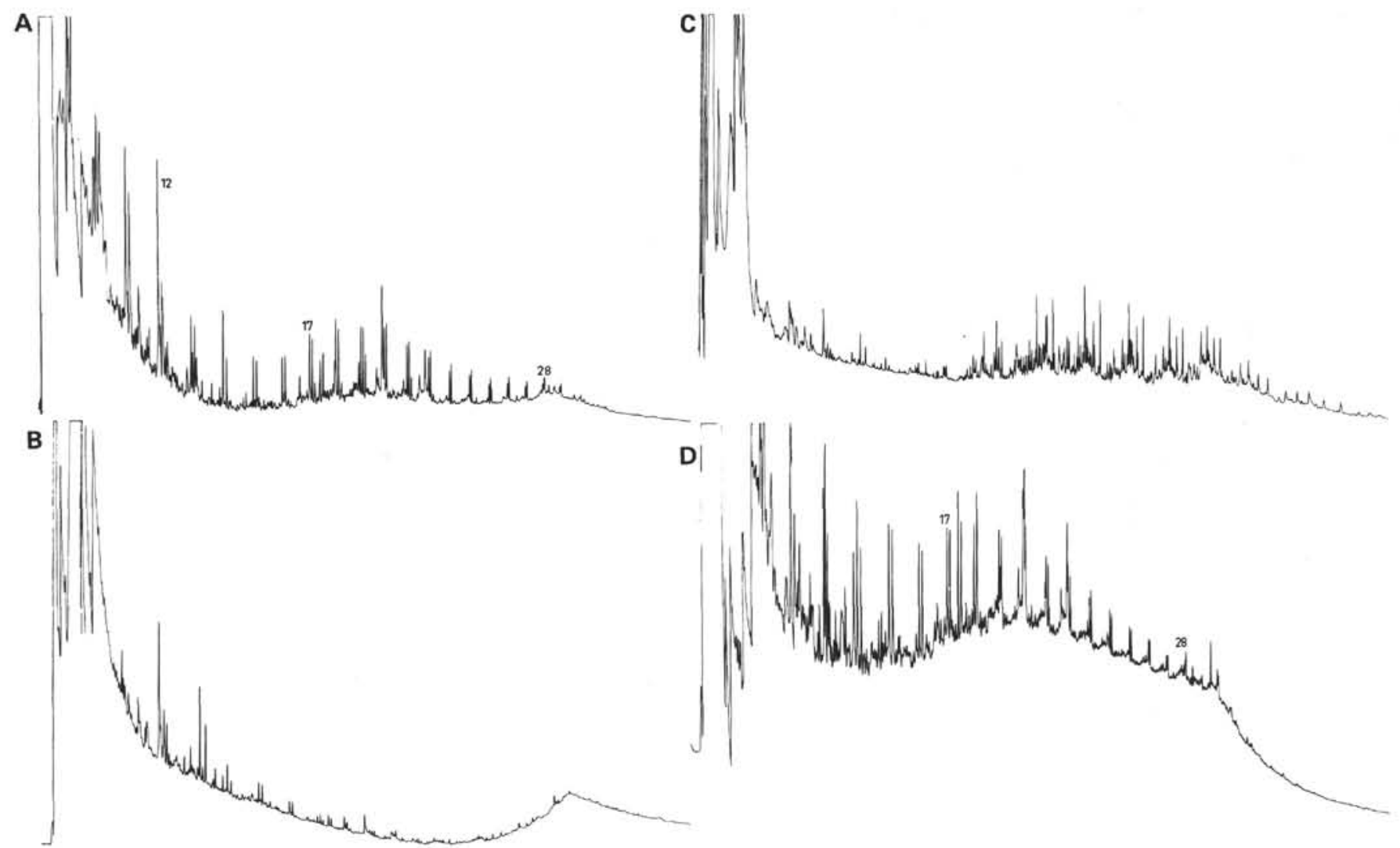

Figure 11. Examples of Cupy/GC traces of kerogen concentrates, Site 481. (Sub-bottom depths are given in parentheses.) A. Sample 481A-12-1, $107-109 \mathrm{~cm}$ (148 m); B. Sample 481A-14-3, 50-52 cm (169 m); C. Sample 481A-14-4, 2-4 cm (170 m); D. Sample 481A-20-1, 60-62 cm (223 m).

extensively altered. The amount of pyrolyzable material appears to be low and its source unknown. The multiplet in the $n-\mathrm{C}_{12}$ region is the dominant feature; the pyrogram generally lacks other interpretable information.

Sample 481A-14-4, 2-4 cm occurs only slightly deeper (1 m) than Sample 481A-14-3, 50-52 cm, and the kerogen pyrogram (Fig. 11C) lacks any evidence of alkene/alkane doublets. Instead, seven or eight broad humps in the $\mathrm{C}_{17}-\mathrm{C}_{30}$ region are the major characteristic features. On top of each hump is a triplet of peaks, which appear to form three homologous series. This pyrogram has only a small contribution from the multiplet in the $n-C_{12}$ region.

Sample 481A-14-4, $52-54 \mathrm{~cm}$ is $50 \mathrm{~cm}$ lower than Sample 481A-14-4, 2-4 cm, and its kerogen program is very similar. The series of broad humps and associated triplets are present. This sample also has a significant contribution from the multiplet in the $\mathrm{C}_{12}$ region, plus a complex distribution of other components in this lower molecular weight region.

The appearance of these two pyrograms is quite different from any of the other pyrograms produced by thermally altered kerogens in this study. The multiple emplacement of the sill complex in this hole indicates that these two samples may represent "bituminized kerogens" (Peters et al., 1979). The "pressure-cooking" effect on the trapped kerogen and liquids produced by thermal degradation of the organic material could cause them to recombine and form a coke-like material similar to mesophase formation in coal (Durand, 1980; Van Krevelen, 1961).

Sample 481A-18-1, 27-29 cm occurs directly beneath the sill, and the pyrogram of this kerogen shows no indication of any extensive alteration. The extract shows no fluorescence, which also indicates the absence of any major thermal alteration. The dominant features of the pyrogram are the alkene/alkane doublets ranging from $\mathrm{C}_{9}$ to $\mathrm{C}_{31}$, with no odd/even carbon predominance and maximizing at $\mathrm{C}_{20}$. Prist-1-ene and prist-2-ene also occur in approximately equal amounts. The pyrogram is very similar in appearance to that of Sample 481A-20-1, $60-62 \mathrm{~cm}$ as shown in Figure 11D.

The kerogen pyrogram of Sample 481A-20-1, 60-62 $\mathrm{cm}$ is virtually identical to the surface sample and Walvis Bay diatomaceous ooze pyrograms (Fig. 8). Alkene/ alkane doublets occur throughout the pyrogram and are predominant below $\mathrm{C}_{20}$; prist-1-ene and prist-2-ene are present in a 1:1 ratio and are more abundant than the $\mathrm{C}_{17}$ doublet. Steranes and triterpanes are present in the $\mathrm{C}_{30}$ region, and the complex unresolved humps are also a prominent feature of the pyrogram.

It would appear, therefore, that the two samples beneath the sill are virtually unaffected by the thermal effects of the sill. Likewise, very little alteration of the samples has occurred from the natural geothermal gradient and by diagenesis. 


\section{SUMMARY AND CONCLUSIONS}

The lipids and kerogens from representative samples at shallow and increasing depths and across sill contacts at Sites $474,477-479$, and 481 have been analyzed. The lipids have been characterized by their homolog distributions, molecular markers, and unresolvable components to assess their genetic sources and the resultant thermal alteration effects caused by intrusions into the sediments. The kerogens have been analyzed for their capability of generating pyrolysis products-a measure of the geologic maturity (i.e., the degree of thermal stress accumulated in situ) and the sources of that kerogen.

\section{Site 474}

The lipids of the shallow samples at the mouth of the Gulf are of an autochthonous marine origin and were deposited under oxic conditions (Simoneit, this volume, Pt. 2). The kerogen from Site 474 is unaltered and similar to shallow samples from the other sites.

\section{Site 477}

The lipids of the shallow samples from Site 477 are primarily of an autochthonous marine origin, with a minor influx of terrestrial plant wax. The environmental conditions of sedimentation were partially euxinic, probably as a result of the high deposition rates. Close to and below the sill the lipids are thermally altered. This is indicated by the loss of the carbon-number predominance, the appearance of a broad hump, and the thermodynamic equilibration of certain stereomers of molecular markers. Large amounts of olefins, occurring only in the altered 477 samples, and elemental sulfur are also present. Thermal alteration of lipids is most severe at this site.

Kerogens from Section 477-5-1 and Sample 477-5,CC are virtually identical to surface samples from all the other sites and are representative of unaltered material. Section 477-7-1, a few meters above the sill, shows signs of being altered, presumably as a result of the intrusion. Section 477-7-2 shows an even more dramatic effect of the alteration-a result of its proximity to the sill. A characteristic feature of these thermally altered samples is a multiplet of peaks in the $n$ - $\mathrm{C}_{12}$ region of the pyrogram. Sections $477-17-3$ and $477-20-2$ produce pyrograms very similar in appearance to that of Section 477$7-2$, which indicates a high degree of thermal alteration from the intrusion. Section 477-22-1, 75 meters below the bottom of the sill, produces a pyrogram showing some signs of alteration, as indicated by the multiplet in the $n-\mathrm{C}_{12}$ region; it also has some characteristics of the unaltered samples. It is proposed that this sample has not been affected as much by the sill as by the high heat flow from depth. Finally, the two deepest samples, from Sections 477A-5-1 and 477A-9-1, have similar pyrograms and appear to be more altered than the samples from Section 477-22-1. The high heat flow from greater depth has probably played a greater role in the alteration of these two deep samples than the sill intrusion has.

\section{Site $\mathbf{4 7 8}$}

In the shallow samples, the lipids derived mainly from autochthonous marine and allochthonous terrigenous sources and in about equal proportions. They were deposited under partially euxinic conditions, again a result of the high sedimentation rates. The lipids of the samples from greater depths are essentially unaltered (e.g., in Section 478-35-2) unless they are in closer proximity to sills. The unaltered samples reflect the same sources and depositional conditions as the shallow samples. The distributions of the homologous compounds, the hump, and the degree of isomerization of the molecular markers (e.g., triterpanes) indicate that the lipids of the altered samples have a lower thermal stress than those at Site 477.

For the kerogens, increasing sample depth shows an increase in thermal alteration, as observed for Site 477. The effect of alteration is first noticeable (in the pyrogram) in Sample 478-29-2, 108-110 cm, collected near the sill (about $255 \mathrm{~m}$ ). There is no evidence for a "pressurecooker" effect on the organic matter trapped between the sills as was the case at Site 477. The sills are responsible for most of the thermal alteration in these samples. Intrusions near all the samples virtually eliminate the chance of distinguishing any effect of natural heat flow.

\section{Site $\mathbf{4 8 1}$}

The lipids of the shallow samples in the northern rift are derived primarily from terrigenous sources, with a minor component of autochthonous marine detritus. On the slope (Site 479), these two sources are about equivalent because of the high marine productivity. The environmental conditions were partially euxinic (as in the other areas) because of the high sedimentation rates. The lipids of the thermally altered samples indicate a similar stress; this is also true of the samples at Site 478 . The carbon-number predominance is lost, a broad hump is present, and molecular markers have undergone isomerization; but less amounts of sulfur are present, and olefins occur only in Sample 481A-14-4, 52-54 cm, close to the sill complex.

The kerogens of the three samples from above the sill complex show definite signs of thermal alteration. Two (Samples 481-14-4, 2-4 cm, 481-14-4, 52-54 cm) are unique to the set of samples in this chapter. The series of phenolic-type humps in their pyrograms suggests a recombination of kerogens and liquids in a pressurecooker environment. Below the sill complex, the samples have not been affected, to any extent, by the sill or the natural geothermal gradient, and the pyrograms are very similar to those of the surface samples and the Walvis Bay diatomaceous ooze.

In conclusion, lipids and kerogens are two ideal carbonaceous fractions that complement each other in providing information about the origins and thermal history of the sedimentary organic matter. Kerogen is a very sensitive in situ marker for thermal stress, and the lipids can represent the products of that stress-prod- 
ucts that hydrothermal circulation has moved a distance away.

\section{ACKNOWLEDGMENTS}

We thank Dara Blumfield and Dana Blumfield for technical assistance, E. Ruth for GC/MS data acquisition, and Dr. Barry Batts and Peter D. Jenden for manuscript review. Partial financial assistance from the Department of Energy and Bureau of Land Management (Contract EY-76-S-03-0034, P.A. 134) is gratefully acknowledged. Contribution 2126 of the Institute of Geophysics and Planetary Physics, UCLA.

\section{REFERENCES}

Ageta, H., Shioima, K., and Arai, Y., 1968. Fern constituents: Neohopane, hopene-II, neohopadiene and fernadiene isolated from Adiantum species. Chem. Commun., 1968:1105-1107.

Bracewell, J. M., Robertston, G. W., and Tate, K. R., 1976. Pyrolysis gas chromatography studies on a climosequence of soils in Tussock Grasslands, New Zealand. Geoderma, 15:209-215.

Curray, J. R., Moore, D. G., Aguayo, J. E., et al., 1979. Leg 64 seeks evidence on development of basin in the Gulf of California. Geotimes, 24(7):18-20.

Dastillung, M., and Albrecht, P., 1976. Molecular test for oil pollution in surface sediments. Mar. Pollut. Bull., 7:13-15.

DeJongh, D. C., 1977. Pyrolytic reaction mechanisms. In Jones, C. E. R., and Cramers, C. A. (Eds.), Analytical Pyrolysis: Amsterdam (Elsevier), pp, 261-275.

Didyk, B. M., Simoneit, B. R. T., Brassell, S. C., et al., 1978. Geochemical indicators of palaeoenvironmental conditions of sedimentation. Nature, 272:216-222.

Djerassi, C., Theobald, N., Kokke, W. C., et al., 1979. Recent progress in the marine sterol field. Pure Appl. Chem., 51:1815-1828.

Durand, B., (Ed.), 1980. Kerogen, Insoluble Organic Matter from Sedimentary Rocks: Paris (Editions Technip).

Gallegos, E. J., 1975. Terpane-sterane release from kerogen by pyrolysis GC-MS. Anal. Chem., 47:1524-1528.

Howard, D. L., 1980. Polycyclic triterpenes of the anaerobic photosynthetic bacterium Rhodomicrobium vanniellii [Ph.D. dissert.]. University of California, Los Angeles.

Huang, W.-Y., and Meinschein, W. G., 1979. Sterols as ecological indicators. Geochim. Cosmochim. Acta, 43:739-745.

Jones, C. E. R., and Cramers, C. A. (Eds.), 1977. Analytical Pyrolysis: Amsterdam (Elsevier).

Larter, S. R., 1978. A geochemical study of kerogen and related materials (Ph.D. dissert.]. University of Newcastle-Upon-Tyne, England.

Larter, S. R., and Douglas, A. G., 1978. Low molecular weight aromatic hydrocarbons in coal maceral pyrolysates as indicators of diagenesis and organic matter type. In Krumbein, W. E. (Ed.), Environmental Biogeochemistry and Geomicrobiology (Vol, 1): Ann Arbor (University of Michigan Press), 373-386.

Larter, S. R., Solli, H., Douglas, A. G., et al., 1979. The occurrence and significance of prist-1-ene in kerogen pyrolysates. Nature, 279:405-407.

Maters, W. L., van de Meent, D., Schuyl, P. J. W., et al., 1977. Curie point pyrolysis in organic geochemistry. In Jones, C. E. R., and Cramers, C. A. (Eds.), Analytical Pyrolysis: Amsterdam (Elsevier), 203-216.

Meuzelaar, H. L. C., Haider, K., Nagar, B. R., et al., 1977. Comparative studies on pyrolysis mass spectra of melanins, model phenolic polymers and humic acids. Geoderma, 17:239-252.

Ourisson, G., Albrecht, P., and Rohmer, M., 1979. The hopanoids. Paleochemistry and biochemistry of a group of natural products. Pure Appl. Chem., 51:709-729.

Peters, K. E., Simoneit, B. R. T., Brenner, S., et al., 1979. Vitrinite reflectance-temperature determinations for intruded Cretaceous black shale in the Eastern Atlantic. In Oltz, D. F. (Ed.), Symposium on Low Temperature Metamorphism: Kerogen and Clay Minerals: Pacific Section SEPM, Los Angeles, pp. 53-58.
Philp, R. P., Calvin, M., Brown, S., et al., 1978. Organic geochemical studies on kerogen precursors in recently deposited algal mats and oozes. Chem. Geol., 22:207-231.

Posthumus, M. A., and Nibbering, N. M. M., 1977a. Pyrolysis mass spectrometry of methionine. Organ. Mass Spectrom. 12:334-337. 1977b. Pyrolysis mass spectrometry of model compounds labelled with stable isotopes. In Jones, C. E. R., and Cramers, C. A. (Eds.), Analytical Pyrolysis: Amsterdam (Elsevier), pp. 277-288.

Posthumus, M. A., Nibbering, N. M. M., Boerboom, A. J. H., et al., 1974. Pyrolysis mass spectrometric studies on nucleic acids. Biomed. Mass Spectrom., 1:352-367.

Schulten, H. R., Beckey, H. D., Meuzelaar, H. L. C., et al., 1973. High resolution field ionization mass spectrometry of bacterial pyrolysis products. Anal. Chem., 45:191-195.

Schulten, H. R., Gortz, W., and Stembridge, C. H., 1978. Curie-point pyrolysis and field ionization mass spectrometry of polysaccharides. Anal. Chem., 50:428-433.

Simmonds, P. G., Schulman, G. P., and Stembridge, C. H., 1969. Organic analysis by pyrolysis gas chromatography-mass spectrometry. A candidate experiment for the biological exploration of Mars. J. Chromatogr. Sci., 7:36-41.

Simoneit, B. R. T., 1975. Sources of organic matter in oceanic sediments [Ph.D. dissert.]. University of Bristol, England.

1977a. Leg 41 sediment lipids-Search for eolian organic matter in Recent samples and examination of a black shale. In Lancelot, Y., Seibold, E., et al., Init. Repts. DSDP, 41: Washington (U.S. Govt. Printing Office), 855-858.

, 1977b. Diterpenoid compounds and other lipids in deepsea sediments and their geochemical significance. Geochim. Cosmochim. Acta, 41:463-476.

,1978a. Organic geochemistry of terrigenous muds and various shales from the Black Sea, DSDP Leg 42B. In Ross, D. A., Neprochnov, Y. P., et al., Init. Repts. DSDP, 42, Pt. 2: Washington (U.S. Govt. Printing Office), 749-753. , 1978b. The organic chemistry of marine sediments. In Riley, J. P., and Chester, R. (Eds.), Chemical Oceanography (2nd Ed.) (Vol. 7): New York (Academic), 233-311.

, 1980a. Organic geochemistry of the shales and sapropels of the Cretaceous Atlantic. Proceedings of the 8th International Meeting of Organic Geochemistry, USSR Academy of Science, Moscow.

1980b. The composition, sources and transport of organic matter to marine sediments-The organic geochemical approach. In Thompson, J. A. J. (Ed.), Proceedings of the Symposium on Marine Chemistry into the Eighties: Ottawa (Research Board of Canada).

, in press. Mass spectrometry and ancillary techniques in fossil energy research-An overview. In Filby, R. H. (Ed.), Atomic and Nuclear Methods in Fossil Energy Research: New York (Plenum).

Simoneit, B. R. T., Brenner, S., Peters, K. E., et al., 1978. Thermal alteration of Cretaceous black shale by basaltic intrusions in the Eastern Atlantic. Nature, 273:501-504.

, 1981. Thermal alteration of Cretaceous black shale by diabase intrusions in the Eastern Atlantic: II. Effects on bitumen and kerogen. Geochim. Cosmochim. Acta, 45:1581-1602.

Simoneit, B. R. T., and Kaplan, I. R., 1980. Triterpenoids as molecular markers of paleoseepage in Recent sediments of the Southern California Bight. Mar. Environ. Res., 3:113-128.

Simoneit, B. R. T., and Mazurek, M. A., 1981. Organic geochemistry of sediments from the Southern California Borderland, Deep Sea Drilling Project Leg 63. In Haq, B. U., Yeats, R. S., et al., Init. Repts. DSDP, 63: Washington (U.S. Govt. Printing Office), 837-851.

van de Meent, D., Brown, S. C., Philp, R. P., et al., 1980. Pyrolysishigh resolution gas chromatography and pyrolysis gas chromatography-mass spectrometry of kerogens and kerogen precursors. Geochim. Cosmochim. Acta, 44:999-1013.

Van Krevelen, D. W., 1961. Coal: Amsterdam (Elsevier). 
APPENDIX

Chemical Structures Cited

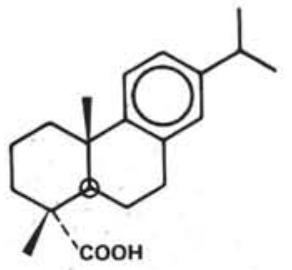

I. Dehydroabietic Acid

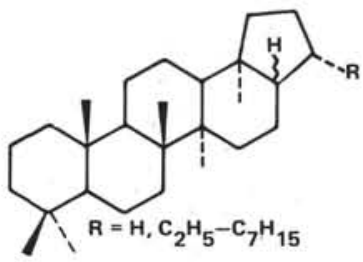

II. Hopanes

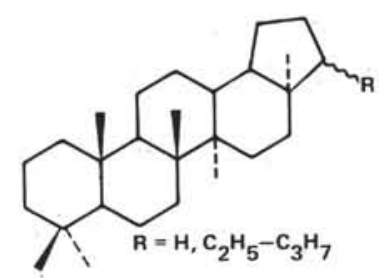

III. iso-Hopanes

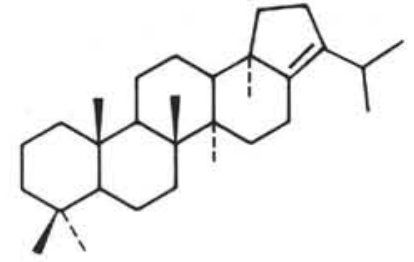

IV. Hop-17(21)-ene

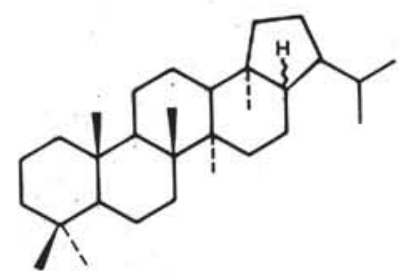

v. Moretanes

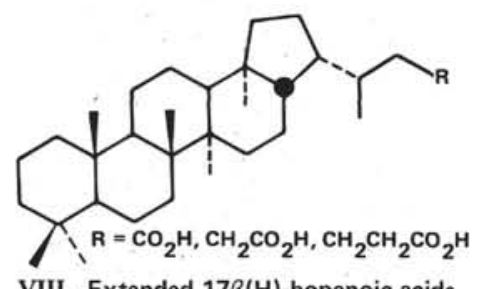

VIII. Extended $17 \beta(\mathrm{H})$-hopanoic acids

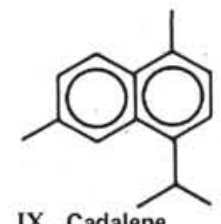

IX. Cadalene

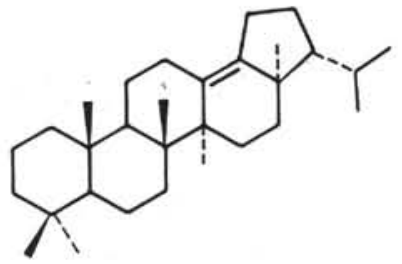

VI. iso-Hop-13(18)-ene

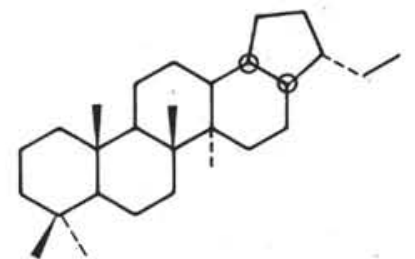

VII. $17 a, 18 a, 21 \beta(\mathrm{H})-28,30$-Bisnorhopane

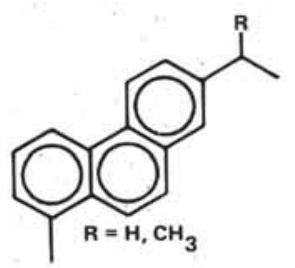

XII. Retenes

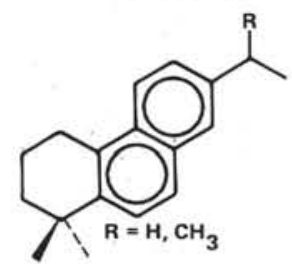

XIII. Simonellites

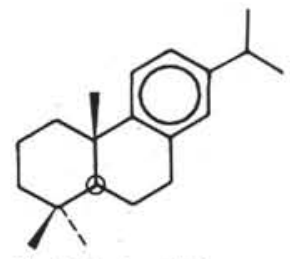

X. Dehydroabietane

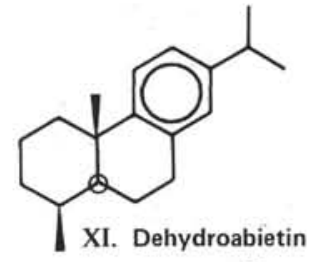

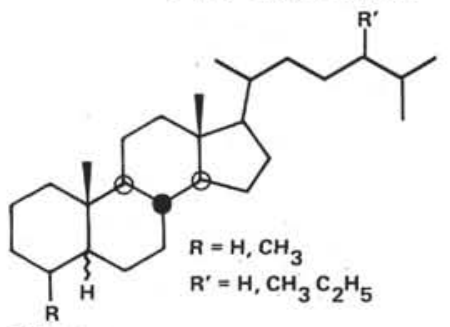

XV. Steranes

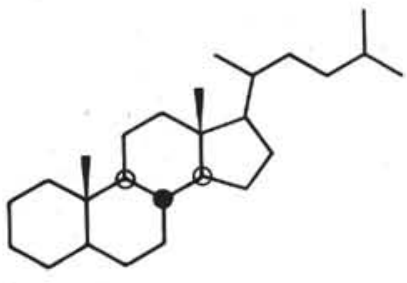

XVI. Norcholestane

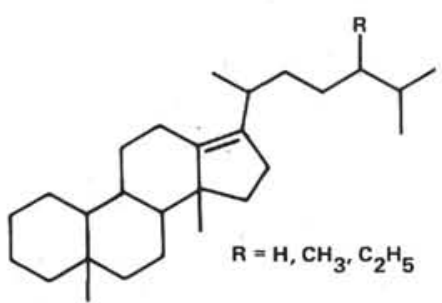

XVII. Diasterenes<smiles>[R]C(CCC(C)C1CCC2C3CCC4=CCCC[C@]4(C)C3CC[C@]12C)C(C)C</smiles>

XIX. Ster-4-enes

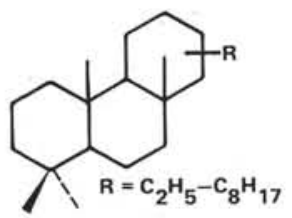

XIV. Extended diterpanes

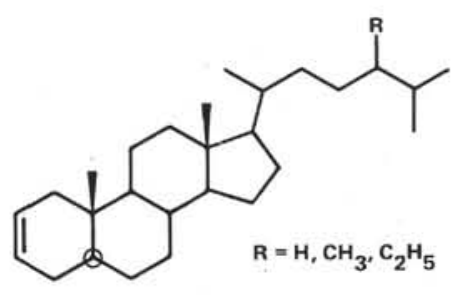

XVIII. Ster-2-enes 